\title{
Impacts of land-use management on ecosystem services and biodiversity: an agent-based modelling approach
}

Thomas J Habib ${ }^{\text {Corresp., }}{ }^{1}$, Scott Heckbert ${ }^{2}$, Jeffrey J Wilson ${ }^{3}$ ， Andrew J K Vandenbroeck ${ }^{4}$ ， Jerome Cranston ${ }^{1}$, Daniel R Farr ${ }^{1}$

\footnotetext{
1 Alberta Biodiversity Monitoring Instutite, Edmonton, Alberta, Canada

2 Alberta Innovates Technology Futures, Edmonton, Alberta, Canada

3 Green Analytics, Guelph, Ontario, Canada

4 Silvacom Ltd., Edmonton, Alberta, Canada

Corresponding Author: Thomas J Habib

Email address: thabib@ualberta.ca
}

The science of ecosystem service (ES) mapping has become increasingly sophisticated over the past 20 years, and examples of successfully integrating ES into management decisions at national and sub-national scales have begun to emerge. However, increasing model sophistication and accuracy - and therefore complexity - may trade-off with ease of use and applicability to real-world decision-making contexts, so it is vital to incorporate the lessons learned from implementation efforts into new model development. Using successful implementation efforts for guidance, we developed an integrated ES modelling system to quantify several ecosystem services: forest timber production and carbon storage, water purification, pollination, and biodiversity. The system is designed to facilitate uptake of ES information into land-use decisions through three principal considerations: 1) using relatively straightforward models that can be readily deployed and interpreted without specialized expertise; 2) using an agent-based modelling framework to enable the incorporation of human decision-making directly within the model; and 3) integration among all ES models to simultaneously demonstrate the effects of a single land-use decision on multiple ES. We present an implementation of the model for a major watershed in Alberta, Canada, and highlight the system's capabilities to assess a suite of ES under future management decisions, including forestry activities under two alternative timber harvest strategies, and through a scenario modelling analysis exploring different intensities of hypothetical agricultural expansion. By using a modular approach, the modelling system can be readily expanded to evaluate additional ecosystem services or management questions of interest in order to guide land-use decisions to achieve socioeconomic and environmental objectives. 


\section{Impacts of land-use management on ecosystem services and}

\section{2 biodiversity: an agent-based modelling approach}

3

4 Thomas J. Habib ${ }^{1}$, Scott Heckbert ${ }^{2}$, Jeffrey J. Wilson ${ }^{3}$, Andrew J. K. Vandenbroeck ${ }^{4}$, Jerome Cranston ${ }^{1}$,

5 and Daniel R. Farr ${ }^{1}$

6

$7 \quad{ }^{1}$ Alberta Biodiversity Monitoring Institute, Edmonton, Alberta, Canada

$8 \quad{ }^{2}$ Alberta Innovates Technology Futures, Edmonton, Alberta, Canada

$9{ }^{3}$ Green Analytics, Guelph, Ontario, Canada

$10{ }^{4}$ Silvacom Limited, Edmonton, Alberta, Canada

11

12 Corresponding author:

13 Thomas J. Habib ${ }^{1}$

14 Email address: thabib@ualberta.ca 


\section{Abstract}

The science of ecosystem service (ES) mapping has become increasingly sophisticated over the past 20 years, and examples of successfully integrating ES into management decisions at national and sub-national scales have begun to emerge. However, increasing model sophistication and accuracy - and therefore complexity - may trade-off with ease of use and applicability to realworld decision-making contexts, so it is vital to incorporate the lessons learned from implementation efforts into new model development. Using successful implementation efforts for guidance, we developed an integrated ES modelling system to quantify several ecosystem services: forest timber production and carbon storage, water purification, pollination, and biodiversity. The system is designed to facilitate uptake of ES information into land-use decisions through three principal considerations: 1) using relatively straightforward models that can be readily deployed and interpreted without specialized expertise; 2) using an agent-based modelling framework to enable the incorporation of human decision-making directly within the model; and 3) integration among all ES models to simultaneously demonstrate the effects of a single land-use decision on multiple ES. We present an implementation of the model for a major watershed in Alberta, Canada, and highlight the system's capabilities to assess a suite of ES under future management decisions, including forestry activities under two alternative timber harvest strategies, and through a scenario modelling analysis exploring different intensities of hypothetical agricultural expansion. By using a modular approach, the modelling system can be readily expanded to evaluate additional ecosystem services or management questions of interest in order to guide land-use decisions to achieve socioeconomic and environmental objectives.

\section{Introduction}



human well-being (Millennium Ecosystem Assessment, 2005). These benefits include tangible products such as food, fuel, and fibre, regulating services that make our environment more liveable, and experiential values such as aesthetic appreciation and recreation. The practice of ES assessment has advanced rapidly in recent years, with methods of quantification progressing from early efforts to estimate the total value of ecosystem services across entire regions using estimates of value for different landcover types ("benefits transfer") (Costanza et al., 1997) to detailed models that capture the actual flow of services from ecosystems to people by explicitly linking ecological production functions to human users (Kareiva et al., 2011; Bagstad et al., 2013a). These mechanistic pathways range from straightforward, spatially uncoupled relationships such as the benefits of carbon sequestration for climate change mitigation, to the close spatial proximity required for insect pollinators to benefit crops, to directional flows such as wetlands that capture flood waters before they reach a developed area (Costanza, 2008). Ecosystem services (ES) information is increasingly viewed as an important part of landuse planning and environmental management (Daily et al., 2009). The ability to simultaneously assess multiple ES and other related socioeconomic and environmental indicators such as food production and biodiversity, provides an understanding of the complex trade-offs associated with land-use (Foley et al., 2005). A variety of multi-ES assessment platforms exist or are currently under development, with varying levels of detail, quantification, generalizability, and usability (Bagstad et al., 2013b). However, if the goal of ES researchers is to influence decisions made by policy- and decision-makers, a model's complexity and functionality must be weighed against its ability to be used and understood by non-experts. The Natural Capital Project's InVEST toolkit 60 (www.naturalcapitalproject.org) is one of the more widely-used modelling packages. In a review 
61 of their experience in applying InVEST to different land-use management issues in several

62 jurisdictions, Ruckelshaus et al. (Ruckelshaus et al., 2013) described several attributes of

63

modelling systems and processes that improved the uptake of ES information by decisionmakers. Interestingly, their experience suggests that stakeholder ES goals are typically broad, such as ensuring an adequate supply of fresh water for agriculture, drinking, and biodiversity, rather than specific measurable objectives typically used in a formal optimization analysis. As such, the appropriate model outputs for these goals may be as simple as relative rankings that can identify priority management locations and activities. Therefore, relatively simple models that use a limited number of input parameters and can be run rapidly on standard desktop computers, but consequently sacrifice some amount of accuracy, precision, or spatial or temporal resolution, may be sufficient for this purpose. Simple models are also likely to be easily visualized and communicated, and therefore more amenable to the iterative science-policy processes most likely to yield on-the-ground results (Ruckelshaus et al., 2013).

Regardless of their complexity, a key capacity of ES models is the ability to estimate how the supply and value of ES change in response to management actions (Ruckelshaus et al., 2013). While representing management outcomes in a model can be accomplished by adjusting parameters to mimic altered management practices, a more holistic solution is to represent human decision-making behaviour as an integrated model component. Spatially-explicit agentbased models (hereafter "ABMs", typically termed "individual-based models" in ecology) are a useful tool for modelling ES, as they are well-suited to represent the reciprocal interactions between ecological and socioeconomic systems that characterize ES (An, 2012; Filatova et al., 2013). The defining feature of ABM are "agents"; these are elements that exist in a model's landscape that have the ability to move, make decisions that can influence other model elements 
84 (cells or other agents) and processes, and contain and track variables. Typical examples of

85

86

87

88

decision-making agents in social-ecological models include landowners, corporations, and individual animals. Incorporating the behaviour of these decision-making entities into a spatially explicit, cell-based model, adds considerable functionality for exploring the two-way linkages between socioeconomic and environmental systems (Parker et al., 2003; Parker, Hessl \& Davis, 2008). For example, the potential supply of timber can be determined by the land cover, forest stand type and age, climate, and other growing conditions, all of which could be simulated in a purely cell-based model. However, converting the potential ES of standing timber volume to the final ecosystem service of wood products actually used by humans requires consideration of the actions of forestry companies that operate mills (i.e. agents). Additionally, the decision of where and how much timber to harvest will depend on environmental policies, wood product prices, and road networks, among other factors. Critically, the ABM structure allows for decisions to be represented at multiple geographic extents, including cell-level, regional (e.g. several forestry companies each control timber harvest in distinct areas), and global extents (e.g. an environmental policy affects forestry activities across the entire study area).

Integrated models that represent multiple ES and decision-making processes within a single, unified platform are capable of demonstrating how a variety of indicators respond to a single management action. Such models are essential to help decision-makers understand tradeoffs among biodiversity, ES, and other socioeconomic indicators such as business revenues, and enable them to balance a variety of public and private values (Nelson et al., 2009; Goldstein et al., 2012). For example, decisions to harvest timber on public land will impact, at minimum, forestry company revenues, carbon storage, water flow and purification, recreational opportunities, and biodiversity. 
While ABMs have previously been used to assess some aspects of ES as they relate to

108 human land-use decisions (Brady et al., 2012; Heckbert et al., 2012; Cong et al., 2014; Villamor

109 et al., 2014), most efforts have tended to include a limited number of ES, and may only include

110 proxies for ES such as areas of landcover types rather than mechanistic models (i.e. production

111 functions; Kareiva et al., 2011). However, detailed ABMs that simultaneously model multiple

112 ES, human decision-making, and the mutual feedbacks between them can quickly become

113 extremely complicated, and may be difficult to communicate within iterative science-policy

114 processes. In consideration of this push-and-pull between ever-more detailed models and

115 usability, we have developed a suite of integrated ecosystem service assessment models within

116 an ABM platform, using relatively straightforward methods as recommended by the experience

117 of Ruckelshaus et al. (2013). We developed models to quantify forest timber production and

118 carbon storage, water purification, pollination, and biodiversity. We provide a demonstration of

119 the modelling system deployed in the North Saskatchewan River watershed in Alberta, Canada,

120 as well as its capabilities to evaluate alternative management and land-use change scenarios.

121

122

\section{Methods}

Study Area

The North Saskatchewan River watershed is a major, $82,000 \mathrm{~km}^{2}$ watershed in the

province of Alberta, Canada, and is home to approximately 1.3 million people (North

Saskatchewan Watershed Alliance, 2012), including the province's capital city of Edmonton

127 (Fig. 1). The region extends across the entire province from west to east, and contains most of

128 the major landcover categories of the province, including mountains, forested areas, parkland,

129 agricultural regions, and urban centres (Fig. 2). Dominant land-use activities in the watershed 
130 include agriculture east of the mountains, forestry in the foothills, energy development, and

131 urban development.

132

133 Modelling Platform and General Model Setup

134 We developed ES models using NetLogo, an open-source, freely available ABM

135 platform (Wilensky, 1999). There are three principal elements in Netlogo: a uniform grid of cells

136 that represents the landscape, user-defined types of agents, and links that can be used to form

137 networks among agents. Both cells and agents can contain as many variables as needed. Models

138 can contain any number of different types of agents. Under the Alberta Township System,

139 parcels of land are divided into $1 / 2$-mile $x$ 1/2-mile "quarter-sections", and many land-use decisions

140 are made at this scale; therefore, we used an $800 \mathrm{~m}$ (i.e. $1 / 2$ mile) cell size to represent this

141 administrative system. While this is a relatively coarse scale for some processes (e.g. simulating

142 surface water flow), using a coarser resolution is a necessary trade-off when modelling a study

143 area this large; using a finer resolution would have been computationally prohibitive. However,

144 the model code is flexible, allowing users to deploy it any cell size that is appropriate for the

145 study area extent and GIS data available, by changing the model variable "area" (see Table A in

146 Article S1).

147 In each grid cell, we calculated the area of each landcover type and human footprint type

148 present within a cell. Thus, while the spatial location of each feature - and the spatial

149 relationship between features - within cells is lost, the approach maintains information on

150 features that are spatially small but may have a disproportionately large influence on the

151 provision and value of ecosystem services (e.g. roads). Spatial landcover data (Alberta

152 Biodiversity Monitoring Institute, 2012a,b, 2014a) include both natural and anthropogenic 
153 features (see Table A in Article S1). In addition to landcover data used by all models, cells also

154 include relevant model-specific variables, as described below. All models operate at an annual

155 time step. See File S2 for a NetLogo file containing the modelling system code.

156

157

Forest Timber and Carbon

158

This model is based on a forest growth algorithm, with stands of timber altering their

volume and carbon balance at each annual time step. We developed forest growth and carbon

accumulation equations as functions of stand age by fitting polynomial curves to forest stand

data from the Canada National Forest Inventory (Natural Resources Canada, 2006) and a

published forest carbon model (Carbon Budget Model of the Canadian Forest Sector, known as

CBM-CFS3; Kurz et al., 2009; Kull et al., 2011), respectively (see Article S1). Based on these

sources, different forest stand types exhibit different timber growth and carbon accumulation

curves, and this is reflected in the model; forests are separated into deciduous, spruce-dominated

or pine-dominated coniferous and mixedwood stands in each of two federally defined ecozones

167

(Montane Cordillera and Boreal Plains) to align with the source data.

Forested land in Alberta is divided into administrative, non-overlapping Forest

Management Units (FMU) that use multiple forms of tenure to allocate timber harvesting rights to companies or individuals (Alberta Agriculture and Forestry, 2016). Large-scale, long-term, area-based Forest Management Agreements (FMA) are the most significant form of tenure, representing 63\% of the timber harvested in Alberta (Alberta Agriculture and Forestry, 2014a). Volume-based coniferous and deciduous Timber Quotas are another significant form of tenure for the forest industry, representing $25 \%$ of timber harvest, much of it within FMUs governed by FMAs. The remaining timber volume is harvested through Timber Permits, industrial salvage, 
176 and non-commercial activities (Alberta Agriculture and Forestry, 2014a). The present model

177 focuses on FMA-based timber harvest, as well as Timber Quotas within FMA areas; combined

178 these two forms of tenure represent approximately $85 \%$ of timber harvest in Alberta.

179 In this model, timber in each FMU is directed to the corresponding mill (pulp or sawmill)

180 operated by the company with tenure rights in that area. For each FMU, a sustainable amount of

181 timber available for harvest in a year, known as the Annual Allowable Cut (AAC), is set out in

182 publicly available forest management planning documents. Working at an annual time-step, the

183 model simulates the spatial pattern and scheduling of timber harvest over several years, with the

184 goal of maximizing profits while harvesting forest stands of the appropriate age (in this case, $\geq$

18580 years old). Harvest decisions are made by agents representing mills, who harvest timber from

186 eligible forest stands (i.e. cells) in the appropriate FMUs until the AAC for the year is reached; in

187 reality, the full AAC is typically not harvested due to economic or operational reasons, and the

188 model accounts for this by only harvesting a percentage of the AAC that is drawn from a normal

189 distribution based on historical harvest rates (Alberta Agriculture and Forestry, 2014b). When a

190 cell is selected for harvest, all of the timber within it is removed, representing the traditional

191 clearcutting technique that dominates forestry in Alberta (Alberta Agriculture and Forestry,

192 2014c).

193 In the model, in order to maximize profits, mills harvest preferentially from stands where

194 the cost to transport timber to the mill is the lowest. Transportation cost was based on the least-

195 cost pathway calculated in ArcGIS (Spatial Analyst; Distance toolset). Because the primary

196 factor driving transportation cost is travel time required due to fixed hourly costs including

197 worker wages, the cost surface accounts for transportation speed by considering whether each

198 cell contains high-speed paved roads, moderate-speed unpaved roads, or other low-speed 
199 corridors that can be used to transport timber, such as pipelines or cut-lines (Table C in Article

200 S1). Once the AAC is reached in each year, mills process the harvested raw timber into wood

201 products based on the mill type (i.e. pulp and paper, lumber, or oriented strand board), and

202 monetary value is calculated based on the market price of each wood product and the operational

203 costs of harvest and processing.

204 Carbon stored in forests is estimated annually, and is affected in the model by timber

205 harvest activities. When timber is harvested from a cell, its age is reset to zero, and the associated

206 amount of carbon, both above- and below-ground, is lost from the environment. However, the

207 model does not address the rate at which carbon sequestered in wood products is released back to

208 the atmosphere as $\mathrm{CO}_{2}$, which can vary widely, from years to decades, depending on the wood

209 products and their use (Skog, 2008; Mckinley et al., 2011).

210

Additionally, this model does not incorporate the influence of natural disturbances such

211

212

213

214

215

216

217

218

219

220

221

as wildfire. Fire is the dominant process shaping the boreal forest, and can play an enormous role in both forest harvest planning and carbon flux. However, despite the existence of sophisticated fire prediction (Parisien et al., 2005) and spread models (Tymstra et al., 2010), the location and size of future fires remains inherently unpredictable. Further, while incorporating a stochastic fire modelling process would be necessary to predict hypothetical future landscapes, the primary objective of this ES modelling suite is to understand current ES values and how they will respond to human management actions, rather than simulating future landcover scenarios.

We ran the simulation for a period of 20 years. Model outputs include the estimated net present value (NPV) of timber harvesting over this time period, the amount of carbon stored above- and below-ground in forests at the end of the 20 -yr simulation, and the change in carbon storage over the simulation. 
223

224

225

226

227

228

229

230

231

232

233

234

235

236

237

238

239

240

241

242

243

244

\section{Water Purification Model}

The water purification model simulates precipitation, overland flow, and surface water flow over a single year, based on the landcover and climate at that point in time. In particular, the model was designed to identify areas contributing to non-point source export of nutrients and sediment (i.e. through surface runoff and erosion), important areas for removing these substances, and impacts to downstream water users. The current model implementation focuses on nutrients (nitrogen, phosphorus, and total suspended solids - TSS) and eroded sediment, which are major determinants of water quality. To set up the model, we used the Spatial Analyst (Hydrology) toolset in ArcGIS 10.1 (ESRI, Redlands, CA) to create a river network based on a 100-m digital elevation model with all sinks filled. After importing the river layer into NetLogo, we created links between all cells containing rivers to form the river network, allowing the model to represent the downstream movement of water and associated nutrient and sediment. We also created agents at points of interest such as tributary outlets and municipal water treatment plants to track model output variables, including water flow and the cumulative annual load of each water quality indicator.

We obtained mean annual precipitation for each cell, based on 1971-2001 climate normals from ClimateWNA (Wang et al., 2012), and calculated runoff from each cell as a percentage of total precipitation, based on runoff coefficients for each landcover type (Donahue, 2013). Because each cell contains multiple landcover types, each cell's runoff coefficient is calculated as the area-weighted sum of runoff coefficients for each landcover type. After the precipitation event, the volume of water that runs off each cell, represented as a "raindrop" agent, moves to the adjacent cell with the lowest elevation, and this downslope movement continues 
245 until it reaches a cell that intersects the river network. At this point water flow moves

246 downstream along the connected river network.

247 Non-point source export of nutrient and sediment are loaded into surface water flow

248 through two different modelling processes. We used export coefficients (measured in $\mathrm{kg} \cdot \mathrm{ha}^{-}$

$24{ }^{1} \cdot \mathrm{mm}^{-1}$ of annual precipitation) calculated for major landcover and human footprint types

250 (Donahue, 2013) to estimate the amount of N, P, and TSS loaded into surface runoff (hereafter,

251 "loading"). Similar to calculating runoff, we used the area-weighted sum of export coefficients

252 for all landcover types present in a cell to calculate the total amount of each nutrient released.

253 Sediment erosion was estimated using the Revised Universal Soil Loss Equation (RUSLE),

254 which estimates erosion based on rainfall, soil characteristics, slope, and land management

255 (Renard et al., 1997). To select the parameters for RUSLE, we relied on published guidance for

256 Canada (Wall et al., 2002) and obtained the necessary soil data from Agriculture and Agri-Food

257 Canada's Soil Landscapes of Canada version 3.2 (Soil Landscapes of Canada Working Group,

258 2010) for our study region.

259 Nutrient removal occurs during overland flow, where a percentage of each raindrop

260 agent's nutrient and sediment load is removed as it flows across downslope cells before reaching

261 the river network. Nutrient and sediment removal percentages are assigned for each landcover

262 type, and the total amount removed by a cell is the area-weighted sum of the landcover types

263 comprising the cell. In addition to producing output maps for nutrient and sediment loading and

264 removal, the model also calculates the amount of nutrients and sediment actually supplied to the

265 river network by each cell; that is, the amount a substance contained in a cell's runoff that

266 eventually makes its way into the river network (i.e. is not retained at some point between the

267 origin cell and the river network). Combined, these three processes predict areas that have 
268 important effects on water quality, as well as identifying priority management areas. In addition

269 to the output maps, the model also outputs a table of water variables that includes the cumulative

270 annual flow and load of nutrients and sediment at water monitoring points of interest along the

271 river network.

272 We calibrated the water purification model using cumulative annual phosphorus load data

273 from 8 tributary basins in the region; the observed water data were estimated from periodic water

274 samples taken from 1985-2008, with the number of observations at each monitoring point

275 ranging from 11 to 241 (mean 83). We conducted a global calibration, varying each of the

276 nutrient export coefficients with 10 unique parameter sets obtained using the Latin Hypercube

277 sampling method (Mckay, Beckman \& Conover, 1979; Abbaspour et al., 2007). Distinct

278 parameter sets were selected for each of three Natural Region areas (Mountains, Foothills, and

279 the same parameters for the Boreal, Parkland, and Grassland, all of which are topographically

280 and geologically similar as part of the Western Canadian Sedimentary Basin, and largely contain

281 similar landcover within the study area). Please refer to the Article S1 for more information on

282 the calibration procedure and results.

284

285

286

287

288

289

290

\section{Pollination}

The pollination model estimates the additional yield of canola that can be attributed to native insect pollinators. Although several local crops may benefit from insect pollination, canola is by far the most valuable Alberta crop that receives such benefits; in 2014, farm cash receipts for canola were $\$ 2.54 \mathrm{~B}$, representing $43 \%$ of Alberta's total crop revenues for that year (Statistics Canada, 2015a). The next-most valuable crop, wheat $(\$ 2.1 \mathrm{~B}$, representing 29\% of Alberta's 2014 crop revenues), does not benefit from insect pollination. Thus, most direct 
291 economic benefits of pollination on Alberta crop production are likely realized through canola

292 production, based on the dominance of canola as a cash crop in Alberta.

Annual crops such as canola can provide a large food resource for insect pollinators, but

294

295

296

297

298

299

300

301

302

303

304

305

306

307

308

309

310

311

312

313

only during a short period of time while in bloom. Additionally, annual crop fields that are

disturbed each year do not provide nesting habitat for ground-nesting bees, which are the most common native pollinators in Alberta (Sheffield, Frier \& Dumesh, 2014). In order for a crop

field to receive benefits from wild pollinators, it must be within the foraging distance of

pollinators occupying nesting habitat, such as undeveloped areas and perennial tame pasture.

Pollinator visitation rates and stability of pollination services have been linked in many areas to proximity to natural or semi-natural areas across multiple crop systems (Ricketts et al., 2008;

Garibaldi et al., 2011). In Alberta, increases in canola yield have been linked to the abundance of uncultivated land within bee foraging distance (generally $<1 \mathrm{~km}$ ), which provides bee nesting habitat (Morandin \& Winston, 2005; Morandin et al., 2007).

We used data from Morandin et al. (2006) to develop a field-level model of canola yield as a function of bee abundance; in turn, bee abundance was estimated as a function of the amount of natural (i.e. undeveloped) and semi-natural (i.e. tame pasture) land within neighbouring cells, representing the amount of bee nesting habitat within foraging distance of each canola field (see Article S1 for equations). This aligns well with Morandin et al. (2006) who defined pollinator nesting habitat within a 750-m buffer around each field. We delineated the boundaries of crop fields using vector-based landcover data (Alberta Biodiversity Monitoring Institute, 2012a,b), as well as small uncultivated areas within them which may represent important pollinator nesting habitat. To represent agricultural polygons on which canola was grown, we used annual crop maps (2009-2012; resolution 30m or 56m) created by Agriculture and Agri-food Canada 
314 (Agriculture and Agri-food Canada, 2012). The model runs at an annual time step; because

315 different crops are typically planted in a given field each year, we used 4 years of crop data to

316 represent typical canola rotations (Alberta Agriculture and Forestry, 2012). Therefore, as the

317 model runs for multiple years, the locations of canola fields change at each time step, repeating

318 every 4 years. In each year of the simulation, the model estimates the additional crop yield due to

319 pollinators, and the monetary value is calculated by multiplying this by the user-defined canola

320 price. When run for multiple years, the economic value is expressed as the net present value,

321 based on a user-defined discount rate; we used a rate of $2 \%$ for the results presented here.

322

Biodiversity Index

324 To assess biodiversity, we used field observations obtained by the Alberta Biodiversity

325 Monitoring Institute to create a biodiversity index to express the degree to which ecological

326 communities are impacted by anthropogenic disturbance (Nielsen et al., 2007). The original data

327 (Alberta Biodiversity Monitoring Institute, 2015) were used to develop detailed species

abundance models as a function of landscape characteristics (Alberta Biodiversity Monitoring

Institute, 2014b). For each species, the abundance model was run for two landscapes: the current

landscape, and a hypothetical "reference" landscape with all human footprint removed and

backfilled with the landcover types that used to be present (Alberta Biodiversity Monitoring

Institute 2014a). The difference between current and reference abundances for each species is

then expressed as a percentage, where a $100 \%$ score represents no change from its reference

abundance, and the score decreases as the current abundance deviates from the reference

Biodiversity Monitoring Institute, 2014b). We averaged the index scores for 447 available 
337 species (comprising 80 birds, 13 mammals, 202 vascular plants, 90 bryophytes, and 62 soil

338 mites) to obtain a single biodiversity index value, which is a representation of how much the

339 entire community has changed due to human activities. Because the overall biodiversity index is

340 an average, individual species responses will be more variable than the overall index suggests;

341 therefore it cannot be used to support decision-making related to individual species of particular

342 management concern, such as species at risk. Instead, it should be used as a coarse filter for

343 biodiversity-related objectives, and complemented by analyses or models of priority species as

344 required for a given management decision. There is no temporal element in the biodiversity

345 model; rather, it estimates the biodiversity index for a single point in time based on landcover

346 characteristics.

347 To deploy the biodiversity model in the suite of ES models, we regressed overall

348 biodiversity index for each cell against the amount of different types of human footprint present

349 (categories included roads, trails, forestry cutblocks, agriculture, and industrial developments) to

350 obtain an overall footprint-biodiversity index equation. This simplified equation (see Article S1)

351 fits the full model very well $\left(r^{2}=0.94\right)$, and allows the ES modelling package to rapidly assess

352 biodiversity condition. The model output is the biodiversity index score for each cell of the study

353 region, measured from 0 to $100 \%$.

Model Integration and Land-use Management Decisions

Each model differs in terms of what modelling elements (i.e. cells, agents, and links) are used; the water purification model draws on all three, the forest timber \& carbon model uses mill agents to control timber harvest, and the pollination and biodiversity models are purely cellular models. Despite the varying amounts of human behaviour directly incorporated into each model, 
360 the integrated nature of the modelling system allows users to evaluate how a given management

361 decision may influence multiple ES; we demonstrate these capabilities of integrated ES

362 assessment models in three ways.

363 First, we ran the water purification and biodiversity models both before and after

364 simulated timber harvest to understand how non-point source nutrient runoff and biodiversity are 365 affected by timber harvest activities. Additionally, we drew on the ABM properties of this model 366 to allow mills to conduct timber harvest activities according to either traditional clearcutting, or

367 variable retention harvesting (Serrouya \& D'Eon, 2004), which may have additional benefits for 368 biodiversity (Fedrowitz et al., 2014). We also demonstrate how this change in forestry practices may impact the NPV of timber harvest. We conducted two simulations, one with all mills using

370 clearcutting such that any harvested cell had all of its timber removed, and one with all mills

371 using variable retention techniques, in which a cell selected for harvest had either $25 \%, 50 \%$, or

$37275 \%$ of its timber volume harvested, with the percentage chosen randomly; this range of harvest

373 intensity is typical of large-scale management experiments (Serrouya \& D'Eon, 2004). While

374 variable retention techniques can include altering both the intensity and spatial pattern of harvest,

375 we only modelled changes in intensity, because fine-scale patterns (e.g. 10 ha, 1 ha, and 0.1 ha

376 patch cut arrays; Huggard \& Vyse, 2002) cannot be represented in an 800m cellular landscape.

377 We omitted pollination from this analysis, as crop production does not occur in the same areas as 378 commercial timber harvest.

379 Second, we highlighted the suite of ES provided in four typical $100 \mathrm{~km}^{2}$ landscapes 380 representative of major land-uses in the study region: unharvested forest, nearby areas that have 381 been harvested for timber, native grasslands, and an agricultural area of annual cropland (Fig. 2).

382 To compare pollination, timber, water purification, and carbon storage across landscapes, we 
383 standardized each of these ES by expressing each landscape's value as a percentage of the

384 maximum value estimated across all four landscapes; for the water model, we chose to compare

385 only one output variable (the amount of phosphorus supplied to the river network). The

386 biodiversity index is already calculated as a percentage, so no additional calculations were

387 necessary to compare across the four landscapes. This analysis can be considered to show how

388 historical land-use decisions have shaped ES provision across the region.

389 Finally, we conducted a scenario modelling analysis to evaluate the impact of potential

390 future agricultural expansion on multiple ecosystem services. The dominant historical land-use

391 change in the study area has been agricultural conversion to produce crops (Fig. 2). While much

392 of this landscape change occurred over the $20^{\text {th }}$ century, a significant amount of conversion has

393 continued more recently; from 2000-2012, nearly 3 million hectares were converted to cropland

394 province-wide, most of which (2.4M ha) was formerly pasture (Haarsma, 2014). We simulated

395 future agricultural expansion by iteratively converting a proportion of the region's remaining

396 pasture into cropland, in 5\% increments. In each simulation, we set the conversion proportion

397 and compared it to a randomly drawn number between 0-1 for each cell; if the random number

398 was lower than the pre-determined conversion proportion, then the cell's pasture was converted.

399 We selected pastures for conversion randomly, which is less realistic than using a probabilistic

400 model based on environmental and socioeconomic factors linked to higher conversion rates.

401 However, the vast majority (77\%) of pastures in the study area occur on soils suitable for crop

402 production (Class 2 and 3 under Alberta's Land Suitability Rating System; Alberta Agriculture

403 and Rural Development, 2013), which Ruan et al. (2016) found to be the most important factor

404 leading to the conversion of pastures to cropland in Alberta. All newly converted cropland was

405 randomly assigned to grow canola in one year out of a 4-year rotation. For each level of 
406 simulated landcover change, we ran the ES models to estimate the total regional amounts of

407 pollination value, total canola revenue, phosphorus runoff, and biodiversity. Forested areas

408 subject to commercial timber harvest do not overlap with this type of landscape change, so we

409 omitted the forest timber and carbon model from this analysis.

410

411 Results

412

Current Values of Ecosystem Services

$413 \quad$ Forest Timber \& Carbon Model

414

Over the 20-year simulation under standard clearcutting practices, the estimated NPV of

415

416

417

418

419

420

421

422

423

424

425

426

427 timber within the study area was projected to be \$719M (Fig. 3A). While forest sector statistics are not available for specific watershed regions, a 1-year simulation for the year 2010 across the entire province estimated timber revenues of \$3.32B (Table B in Article S1), representing 91\% of the recorded total provincial revenues for wood and pulp products of $\$ 3.65 \mathrm{~B}$ for that year (Statistics Canada, 2015b); given that the model only captures the $85 \%$ of timber harvested within Alberta (i.e. FMA-based harvest, including Timber Quotas within FMA areas), the model output aligns reasonably well with the observed forestry revenue from that year.

Forest carbon storage under current conditions was estimated at $2.5 \mathrm{~B}$ tonnes of $\mathrm{CO}_{2}$ equivalent (Fig. 4). Over the 20-year period, an estimated 170M additional tonnes of carbon were sequestered in forested areas, even after accounting for the removal of carbon due to timber harvest. This represents an increase in carbon storage of $6.7 \%$ over the 20 -year period (Fig. 5).

\section{$\underline{\text { Water Purification Model }}$}



region, highlighting areas that are more (or less) important for determining water quality, and where management could be prioritized (e.g. Fig. 6; see additional figures E-J in Article S1).

431 However, to estimate the benefits of water purification actually received by people, it is necessary to identify not just source areas for excess nutrients and sediment, but also what areas impede this harmful flow prior to reaching a service area (Bagstad et al., 2013a). Therefore, we highlight the amount of each substance retained on the landscape contributing to the water supply of the City of Edmonton (Fig. 7), which represents the majority of the region's demand for clean drinking water. In an average year, the model predicts that the contribution area upstream of Edmonton retains $4.4 \mathrm{M} \mathrm{kg}$ of nitrogen, $682 \mathrm{~K} \mathrm{~kg}$ of phosphorus, and $466 \mathrm{M} \mathrm{kg}$ of total suspended solids. points in the river network and observed data for the same locations; only 8 locations in the region had sufficiently frequent water quality data to calculate the annual nutrient loads. The model performed better in agricultural areas compared to the western mountainous region, which is likely due to the origin of nutrient export coefficients we used, which were calculated predominantly from low-order streams in agricultural areas (Donahue, 2013).

$\underline{\text { Pollination Model }}$

Based on a four-year simulation and the 2010 crop price $\$ 461.81 /$ tonne (Canola Council of Canada, 2015), we estimated the value of wild pollinators to canola production in the study area to be $\$ 971 \mathrm{M}$, or up to $\$ 67,000$ per quarter section over that time period (Fig. 8). Farm cash

450 receipt data are only available at the provincial level, but based on similar scenarios run for the 
451 entire province, the amount of income attributable to pollinators (\$2.65B; Table E in Article S1)

452 represents approximately $30 \%$ of revenue from canola production over the $2009-12$ time period

453 (Statistics Canada, 2015a).

454 The average canola yield predicted by the model was 27.3 bushels/acre, which is within 455 the range of yields observed in Alberta from 2002-2003 (Graf, 2013) when the original data were 456 collected by Morandin \& Winston (2006). However, Alberta canola yields have increased by $4573.4 \%$ annually since 2000 (Graf, 2013), and therefore this estimate is low compared to observed 458 yields in more recent years (e.g. 30.8 and 37 bushels/acre in 2009 and 2010, respectively; 459 Alberta Agriculture and Forestry, 2010, 2011). Collection of new field data may help account for 460 additional explanatory factors, including interactions between native and managed pollinators 461 such as honeybees, variability among different strains of canola, differences in pollinator 462 communities, climate, and landcover conditions across Alberta, and potential negative effects of 463 planting canola in continuous or very short rotations (Cathcart et al., 2006; Harker et al., 2014). 464 Additionally, conducting manipulative experiments comparing canola yield inside and outside of 465 pollinator exclosures would isolate the contribution of pollination and provide a dataset to 466 validate this or any other pollination model.

468 Biodiversity Model estimated at 51.6\%. The index score varied regionally (Fig. 9), from the nearly completely 471 undeveloped national parks in the western mountains ( $99 \%$ biodiversity score), to the adjacent

472 foothills region (77\% biodiversity score), to urban areas and widespread agriculture in the central 473 and eastern portions of the region (40\% biodiversity score). 
475 Effects of Timber Harvest

476 The timber NPV under variable retention was estimated at $\$ 693 \mathrm{M}$ (Fig. 3B), a decrease

477 of \$26.7 million compared to the clearcutting simulation, representing 3.7\% in foregone profits

478 over the 20 year time horizon (Fig. 10). The 20-year clearcutting simulation led to an

479 approximately $1 \%$ increase in nitrogen and phosphorus supplied to the North Saskatchewan

480 River, and a 3\% increase in TSS supply; the effects of variable retention harvest on water and

481 carbon model outputs were similar to those of clearcutting (Fig. 10).

482

Following 20 years of simulated timber harvest, the biodiversity index decreased in areas

impacted by harvest activities. Unsurprisingly, moving from clearcutting to variable retention

484

485

486

487

488

489

490

491

492

493

494

495

496

timber harvest leads to biodiversity impacts that are more extensive but less locally severe (Fig.

11). However, while the model is capable of predicting the spatial pattern of biodiversity

responses to variable retention timber harvest, it is inappropriate for assessing the actual index

values in areas subject to this type of timber harvest. This is because the mosaic of harvested and

standing trees created by variable retention logging essentially represents a distinct new

landcover type, rather than simply a smaller area of clearcut as the model currently treats it.

Because this type of disturbance has less severe impacts on many species (Schieck \& Song, 2006) the biodiversity index scores will be artificially low.

\section{Variation in Suites of Ecosystem Services}

The differences in the suite of ES provided by the four representative landscapes

(grassland, agriculture, unharvested forest, and harvested forest) are dramatic, and all four landscapes show a marked specialization toward a subset of ES (Fig. 12). Note that a high 
497 "phosphorus runoff" score indicates more runoff, and therefore lower provision of clean water.

498 All five axes in Fig. 12 are scaled from 0-100\% for ease of comparison, rather than showing

499 absolute ES values; therefore, direct comparisons between different ES are inappropriate, but the

500 changes in a given ES across regions demonstrate the trade-offs associated with each land-use.

501 For example, comparing the logged and un-logged forested landscapes, conducting forestry

502 activities to obtain timber value was associated with relatively small decreases in carbon storage, 503 and biodiversity, but a marked increase in phosphorus runoff. Similarly, the historical shift in the

504 eastern part of our study area from native grasslands to annual cropland shows a dramatic

505 increase in phosphorus runoff, and a considerable decrease in the biodiversity index (Fig. 12).

506

507

508

509

510

511

512

513

514

515

516

517

518

519

Agricultural Expansion Scenario Modelling

In general, converting pasture to cropland for canola production increased total crop

revenues and total pollinator value, but with diminishing returns as the proportion of land converted increased, and even declining in the case of pollinator value (Fig. 13). At all levels of conversion, the mean pollinator value per field decreased as pasture - and therefore pollinator nesting habitat - was removed (Fig. 13). Water purification declined across the landscape, with an increasing amount of nutrients loaded into runoff, and decreased capacity to filter this runoff (Fig. 14). Finally, the biodiversity index declined approximately linearly (Fig. 14).

In addition to the general trends, we highlight the results at the $40 \%$ conversion level, corresponding approximately to the observed conversion rate from 2000-2012 within our study area (Haarsma, 2014). This scenario corresponded to approximately 400,000 hectares of pasture being converted to cropland, representing a $15 \%$ increase in annual cropland area. In this conversion scenario, we found a $9 \%$ increase in total canola revenue, a $6 \%$ increase in total 
520 pollination value, but a $1 \%$ decline in average pollinator value per cell; that is, the lower number

521 of pollinators per field was offset by the increase in area under canola cultivation. Within the

522 portion of the study area dominated by agriculture (comprising the parkland, grassland, and

523 boreal natural regions in Fig. 1), total phosphorus supplied to the river network increased by

$5243.1 \%$, and the biodiversity index declined by 1.5 points, from $39.9 \%$ to $38.4 \%$.

525

526 Discussion

527 Integrated Ecosystem Services Models and Trade-Offs

528 By combining multiple ES models within an ABM platform, we were able to quantify the

529 trade-offs that are inherent to any land-use management activity, but typically hidden (Fig. 10,

530 Fig. 12). When new management practices are being considered, understanding these trade-offs

531 is a critical part of the cost-benefit analysis. For example, shifting from clearcutting to variable

532 retention timber harvest results in foregone profit for forestry companies; the integrated model

533 results provide valuable information to help decision-makers determine whether the gain in other

534 ES justifies this monetary cost.

535 Trade-offs may include changes in the production of ES, but also the abilities of people to

536 access and use existing ES. In the provided example of agricultural expansion, adding new crop

537 fields reduces the biophysical supply of an ES (loss of pollinator habitat), but - to a point -

538 increases the ability of people to benefit from the service by creating more crop fields to receive

539 those pollination benefits. In this case, there is a one-to-one exchange between land providing

540 service provision and receiving benefits, as every parcel of new crop acreage comes at the

541 expense of an equal area of pollinator nesting habitat. While the relationship between increasing

542 access and the biophysical supply of a given ES will not always be in direct competition - or 
543 even related at all (Wieland et al., 2016) - this example demonstrates the complexities of

544 evaluating the wide-ranging effects of land-use management, and underscores the need for

545 models to consider both the biophysical supply of ES, as well as how they are actually used by

546 people.

547 When considering implementing a land-use management action, it is important to

548 understand how intensely a given management action should be applied in order to achieve the

549 desired environmental and/or socioeconomic objectives. By providing the ability to quickly run

550 multiple iterations of a scenario at different conversion rates, this modelling system allows users

551 to understand the "production curves" of ES and other socioeconomic indicators (Fig. 13, Fig.

552 14) to identify the optimal level of a given management action.

553

554 Modelling Human Decision-Making Behaviour

555 Modelling human behaviour is complex, and models are unlikely to capture all of the

556 factors that real-world decisions will be based on. For example, mill agents in the timber model

557 base their decisions on where to harvest based on the transportation costs, in order to maximize

558 profits. However, decisions behind harvest siting are typically more complex, considering factors

559 such as environmental performance (Alberta-Pacific Forest Industries, 2007) or integrating

560 landscape planning with other resource companies (Government of Alberta, 2015).

561 In addition to external factors motivating human behaviour, there may also be complex

562 feedbacks and interdependencies among multiple actors in a given scenario. For example, in our

563 agricultural expansion analysis, we treated all cells as independent decision-makers; however,

564 cell- or field-level decisions will be interdependent for a number of reasons. This includes

565 multiple cells being owned by the same individual, and the opportunity for a crop field to benefit 
566 from "free-riding" on pollinator-friendly management implemented in neighbouring cells, with

567 the cost of that management borne by another landowner. While we did not model these complex

568 interdependencies in the current analysis, agent-based modelling platforms are an appropriate

569 tool for simulating such a system (Cong et al., 2014). Our modelling package could be further

570 developed to address them in the future, while also providing valuable information on how other

571 socio-ecological indicators are affected as a result of agricultural land-use management decisions

572 (e.g. Fig. 14).

573

574

Applying Ecosystem Service Models to Land-use Planning

While this modelling system can provide guidance on how to achieve a variety of ES-

576 related goals, it requires complementary information from other sources to fully address most

577 questions. For example, in our study region of central Alberta, blue-green algae blooms in large,

578 recreational lakes are relatively common during summer months (Pick, 2016). The water model

579 output layers can be analyzed solely within the watershed of a lake of interest to identify

580 important areas of non-point source phosphorus pollution that are responsible for the algal

581 blooms (Trimbee \& Prepas, 1987). However, determining whether a given level of phosphorus

582 reduction will be sufficient to eliminate algal blooms requires a detailed understanding of in-lake

583 water chemistry (Pick, 2016), which a regional model such as ours cannot provide. Similarly,

584 understanding the monetary benefits of eliminating algal blooms, such as increased property

585 values and recreational tourism (Keeler et al., 2012), require detailed economic models; this

586 information may be required for decision-makers to determine an acceptable budget for water

587 quality improvement measures.

588 
589

590

591

592

593

594

595

596

597

598

599

600

601

602

603

604

605

606

607

608

609

610

611

\section{Conclusions}

We present an implementation of an ES modelling suite for a region in Alberta, Canada, but the majority of underlying modelling processes are generalizable to other jurisdictions if the appropriate data and GIS layers are available. Even the timber \& carbon model, which draws on Alberta's unique FMA system, can largely be adapted to work in other jurisdictions where mills select specific cutblock locations from a larger forested area. In all cases of implementing this modelling suite in other jurisdictions, careful collection of data and parameter selection are essential.

Despite our focus on ES, including a separate model to evaluate biodiversity is necessary because ES are a poor proxy for biodiversity and vice versa. Despite the many linkages between biodiversity and ES, the relationship between biodiversity and a given ES is not always positive, or indeed, even present (Cardinale et al., 2012). In some cases, it may be most appropriate to consider the value of biodiversity as a component of other final ecosystem services, for example the additional tourism dollars from recreational bird watching in areas of high avian diversity. However, leaving aside these economic values, the intrinsic value of biodiversity is important to many stakeholders in its own right (Soulé, 2013), and cannot be addressed by the instrumental or economic valuation that is often the focal point of ES studies. Incorporating a separate assessment of biodiversity alongside the instrumental values of ecosystem services provides a safeguard against ignoring the intrinsic value of nature, while also providing information on indicators of interest to the widest possible range of stakeholders (Tallis \& Lubchenco, 2014). The ability to analyze landscapes and land-use management decisions using integrated, multi-ES models provides considerable insight into trade-offs between ES and other socioeconomic indicators. While the modelling suite we present is far from an exhaustive list of 
612 ecosystem services, it helps contribute to a fuller accounting of what is gained and lost through

613 human land-use activities; future work to create additional assessment models, such as for

614 grassland carbon storage, food production, and recreational values, would expand its utility.

615 Likewise, although we present only two examples of land-use management decision-making,

616 namely timber harvesting systems and agricultural expansion, the modelling suite can be further

617 developed with additional, targeted sub-models to endogenously evaluate how other candidate

618 land-use policies and actions can influence human decision-making and consequently ecosystem

619 services. In particular, this ability to hard-wire human decisions into the model distinguishes this 620 system from other existing ES modelling packages (Table 1; see Table 2 in Bagstad et al., 2013b

621 for attributes of other modelling systems). By explicitly linking human decision-making and ES

622 outcomes in a unified modelling platform, this modelling system allows stakeholders to evaluate

623 the opportunities and trade-offs to make informed decisions for achieving land-use planning 624 goals.

625

626 Acknowledgements

627 We thank D. Huggard for supplying biodiversity equations, and S. Neufeld for providing water 628 quality monitoring data. 


\section{References}

630 Abbaspour KC., Yang J., Maximov I., Siber R., Bogner K., Mieleitner J., Zobrist J., Srinivasan

631 R. 2007. Modelling hydrology and water quality in the pre-alpine/alpine Thur watershed

632 using SWAT. Journal of Hydrology 333:413-430. DOI: 10.1016/j.jhydrol.2006.09.014.

633 Agriculture and Agri-food Canada. 2012. AAFC Annual Crop Inventory. Available at

634 http://open.canada.ca/data/en/dataset/ba2645d5-4458-414d-b196-6303ac06c1c9

635 Alberta Agriculture and Forestry. 2010. Alberta 2009 Crop Season in Review. Available at

636 http://www1.agric.gov.ab.ca/\$department/deptdocs.nsf/all/sdd13100?opendocument

637

638

639

640

641

642

643

644

645

646

647

648

649

Alberta Agriculture and Forestry. 2011. Alberta 2010 Crop Season in Review. Available at http://www1.agric.gov.ab.ca/\$department/deptdocs.nsf/all/sdd13561?opendocument

Alberta Agriculture and Forestry. 2012. Canola Rotations in Alberta and Yield Performance.

Alberta Agriculture and Forestry. 2014a. Sustainable Forest Management: 2013 Facts and Statistics - Timber Volume Harvested. Available at http://www.agric.gov.ab.ca/app21/forestrypage?cat1=Forest Management\&cat2=Forest Management Facts \%26 Statistics

Alberta Agriculture and Forestry. 2014b. Sustainable Forest Management: 2013 Facts and Statistics - Annual Allowable Cut. Available at http://www.agric.gov.ab.ca/app21/forestrypage?cat1=Forest Management\&cat2=Forest Management Facts \%26 Statistics

Alberta Agriculture and Forestry. 2014c. Sustainable Forest Management: 2013 Facts and Statistics - Area Harvested. Available at 
650 http://www.agric.gov.ab.ca/app21/forestrypage?cat $1=$ Forest Management\&cat2=Forest 651 Management Facts \%26 Statistics

652 Alberta Agriculture and Forestry. 2016. Forest Tenure - Forest Management. Available at 653 http://www.agric.gov.ab.ca/app21/forestrypage?cat $1=$ Forest Management\&cat2=Forest 654 Tenure

655 Alberta Agriculture and Rural Development. 2013. Land Suitability Rating System (LSRS) 656 features for the agricultural area of Alberta. Environmental Stewardship Division, Agri657 Environmental Branch.

658

659

660

661

662

663

664

665

666

667

668

669

670

Alberta Biodiversity Monitoring Institute. 2012a. ABMI Wall-to-wall Land Cover Map 2010. Version 2.1. Available at ftp://ftp.public.abmi.ca/GISProduct/LandCover/W2W2010/LandcoverMapABMIGuide201 0v1.0.pdf (accessed April 13, 2016).

Alberta Biodiversity Monitoring Institute. 2012b. ABMI Human Footprint Map 2010. Version 1.1. Available at ftp://ftp.public.abmi.ca/GISProduct/HumanFootprint/2010/version1.1/ABMI_HFGuide_201 0_Version1.1_Public.pdf(accessed April 13, 2016).

Alberta Biodiversity Monitoring Institute. 2014a. Alberta Backfilled Wall-to-Wall Vegetation Layer Metadata. Version 4. Edmonton, Alberta.

Alberta Biodiversity Monitoring Institute. 2014b. Manual for Species Modeling and Intactness. Version 2014-09-25. Available at www.abmi.ca (accessed April 13, 2016).

Alberta Biodiversity Monitoring Institute. 2015. ABMI Data Portal. Available at 
671 http://abmi.ca/home/data/welcome-data-portal.html

672 Alberta-Pacific Forest Industries. 2007. Alberta-Pacific FMA Area Forest Management Plan 673 (Revised). Available at

674 http://www1.agric.gov.ab.ca/\$department/deptdocs.nsf/all/formain15754/\$file/ALPAC-

$675 \quad$ FMP-ExecutiveSummary-Sep2007.pdf

676 An L. 2012. Modeling human decisions in coupled human and natural systems: Review of agent677 based models. Ecological Modelling 229:25-36. DOI: 10.1016/j.ecolmodel.2011.07.010.

678 Bagstad KJ., Johnson GW., Voigt B., Villa F. 2013a. Spatial dynamics of ecosystem service

679 flows: A comprehensive approach to quantifying actual services. Ecosystem Services 680 4:117-125. DOI: 10.1016/j.ecoser.2012.07.012.

681 Bagstad KJ., Semmens DJ., Waage S., Winthrop R. 2013b. A comparative assessment of 682 decision-support tools for ecosystem services quantification and valuation. Ecosystem 683 Services 5:27-39. DOI: 10.1016/j.ecoser.2013.07.004.

684 Brady M., Sahrbacher C., Kellermann K., Happe K. 2012. An agent-based approach to modeling 685 impacts of agricultural policy on land use, biodiversity and ecosystem services. Landscape 686 Ecology 27:1363-1381. DOI: 10.1007/s10980-012-9787-3.

687 Canola Council of Canada. 2015. Current canola oil, meal, and seed prices. Available at 688 http://www.canolacouncil.org/markets-stats/statistics/current-canola-oil,-meal,-and-seed$689 \quad$ prices

690 Cardinale BJ., Duffy JE., Gonzalez A., Hooper DU., Perrings C., Venail P., Narwani A., Mace 691 GM., Tilman D., A.Wardle D., Kinzig AP., Daily GC., Loreau M., Grace JB., Larigauderie 
692

693

694

695

696

697

698

699

700

701

702

703

704

705

706

707

708

709

710

711

712

A., Srivastava DS., Naeem S. 2012. Biodiversity loss and its impact on humanity. Nature 489:326-326. DOI: 10.1038/nature11373.

Cathcart RJ., Topinka AK., Kharbanda P., Lange R., Yang R-C., Hall LM. 2006. Rotation length, canola variety and herbicide resistance system affect weed populations and yield. Weed Science 54:726-734. DOI: 10.1614/WS-05-041R1.1.

Cong RG., Smith HG., Olsson O., Brady M. 2014. Managing ecosystem services for agriculture: Will landscape-scale management paya. Ecological Economics 99:53-62. DOI: 10.1016/j.ecolecon.2014.01.007.

Costanza R., d'Arge R., de Groot R., Farber S., Grasso M., Hannon B., Limburg K., Naeem S., O’Neill R V., Paruelo J., Raskin RG., Sutton P., van den Belt M. 1997. The value of the world's ecosystem services and natural capital. Nature 387:253-260. DOI: $10.1038 / 387253 \mathrm{a} 0$.

Costanza R. 2008. Ecosystem services : Multiple classification systems are needed. Biological Conservation 141:350-352.

Daily GC., Polasky S., Goldstein J., Kareiva PM., Mooney HA., Pejchar L., Ricketts TH., Salzman J., Shallenberger R. 2009. Ecosystem services in decision making: Time to deliver. Frontiers in Ecology and the Environment 7:21-28. DOI: 10.1890/080025.

Donahue WF. 2013. Determining Appropriate Nutrient and Sediment Loading Coefficients for Modeling Effects of Changes in Landuse and Landcover in Alberta Watersheds

Fedrowitz K., Koricheva J., Baker SC., Lindenmayer DB., Palik B., Rosenvald R., Beese W., Franklin JF., Kouki J., Macdonald E., Messier C., Sverdrup-Thygeson A., Gustafsson L. 
713

714

715

716

717

718

719

720

721

722

723

724

725

726

727

728

729

730

731

732

733

734
2014. Can retention forestry help conserve biodiversity? A meta-analysis. Journal of Applied Ecology 51:1669-1679. DOI: 10.1111/1365-2664.12289.

Filatova T., Verburg PH., Parker DC., Stannard CA. 2013. Spatial agent-based models for socioecological systems: Challenges and prospects. Environmental Modelling and Software 45:1-7. DOI: 10.1016/j.envsoft.2013.03.017.

Foley JA., Defries R., Asner GP., Barford C., Bonan G., Carpenter SR., Chapin FS., Coe MT., Daily GC., Gibbs HK., Helkowski JH., Holloway T., Howard EA., Kucharik CJ., Monfreda C., Patz JA., Prentice IC., Ramankutty N., Snyder PK. 2005. Global consequences of land use. Science 309:570-4. DOI: 10.1126/science.1111772.

Garibaldi LA., Steffan-Dewenter I., Kremen C., Morales JM., Bommarco R., Cunningham SA., Carvalheiro LG., Chacoff NP., Dudenhöffer JH., Greenleaf SS., Holzschuh A., Isaacs R., Krewenka K., Mandelik Y., Mayfield MM., Morandin LA., Potts SG., Ricketts TH., Szentgyörgyi H., Viana BF., Westphal C., Winfree R., Klein AM. 2011. Stability of pollination services decreases with isolation from natural areas despite honey bee visits. Ecology letters 14:1062-72. DOI: 10.1111/j.1461-0248.2011.01669.x.

Goldstein JH., Caldarone G., Duarte TK., Ennaanay D., Hannahs N., Mendoza G., Polasky S., Wolny S., Daily GC. 2012. Integrating ecosystem-service tradeoffs into land-use decisions. Proceedings of the National Academy of Sciences 109:7565-7570. DOI: 10.1073/pnas.1201040109.

Government of Alberta. 2015. ILM Success Story: Al-Pac-Opti/Nexen Integrated Planning. Available at http://esrd.alberta.ca/lands-forests/integrated-land- 
735 Graf RJ. 2013. Crop Yield and Production Trends in Western Canada. Available at

736 http://www.pgdc.ca/pdfs/wrt/Crop Yield Trends FINAL.pdf (accessed April 13, 2016).

737 Haarsma DG. 2014. Spatial analysis of agricultural land Conversion and its associated drivers in 738 Alberta. MSc Thesis, University of Alberta.

739

Harker KN., O 'Donovan JT., Turkington TK., Blackshaw RE., Lupwayi NZ., Smith EG., Johnson EN., Gan Y., Kutcher HR., Dosdall LM., Peng G. 2014. Canola rotation frequency impacts canola yield and associated pest species. Canadian Journal of Plant Science 95:920. DOI: 10.4141/CJPS-2014-289.

Heckbert S., Russell-Smith J., Reeson A., Davies J., James G., Meyer C. 2012. Spatially explicit benefit-cost analysis of fire management for greenhouse gas abatement. Austral Ecology 37:724-732. DOI: $10.1111 / j .1442-9993.2012 .02408 . x$.

Huggard DJ., Vyse A. 2002.Comparing Clearcutting and Alternatives in a High-elevation Forest: Early Results from Sicamous Creek. Available at https://www.for.gov.bc.ca/hfd/pubs/docs/En/En63.pdf (accessed April 13, 2016).

Kareiva P., Tallis H., Ricketts TH., Daily GC., Polasky S. (eds.) 2011. Natural Capital: Theory and Practice of Mapping Ecosystem Services. Oxford University Press. DOI: 10.1093/acprof:oso/9780199588992.001.0001.

Keeler BL., Polasky S., Brauman KA., Johnson KA., Finlay JC., O’Neill A., Kovacs K., Dalzell B. 2012. Linking water quality and well-being for improved assessment and valuation of ecosystem services. Proceedings of the National Academy of Sciences of the United States of America 109:18619-24. DOI: 10.1073/pnas.1215991109. 
756 Kull SJ., Rampley S., Morken GJ., Metsaranta J., Neilson ET., Kurz WA. 2011. Operational-

757 Scale Carbon Budget Model of the Canadian Forest Sector (CBM-CFS3) Version 1.2:

758 User's Guide. Edmonton, Alberta.

759 Kurz WA., Dymond CC., White TM., Stinson G., Shaw CH., Rampley GJ., Smyth C., Simpson

760 BN., Neilson ET., Trofymow JA., Metsaranta J., Apps MJ. 2009. CBM-CFS3: A model of

761 carbon-dynamics in forestry and land-use change implementing IPCC standards. Ecological

762 Modelling 220:480-504. DOI: 10.1016/j.ecolmodel.2008.10.018.

763

764

765

766

767

768

769

770

771

772

773

774

775

776

Mckay MD., Beckman RJ., Conover WJ. 1979. A Comparison of Three Methods for Selecting Values of Input Variables in the Analysis of Output from a Computer Code. Technometrics 21:239-245. DOI: doi:10.2307/1268522.

Mckinley DC., Ryan MG., Birdsey RA., Giardina CP., Harmon ME., Heath LS., Houghton RA., Jackson RB., Morrison JF., Murray B., Pataki DE., Skog KE., Mckinley DC., Ryan MG., Birdsey RA., Giardina CP., Harmon ME., Heath LS., Houghton RA., Jackson RB., Morrison JF., Murray BC., Pataki DE., Skog KE. 2011. A synthesis of current knowledge on forests and carbon storage in the United States. Ecological Applications 21:1902-1924.

Millennium Ecosystem Assessment. 2005. Ecosystems and Human Well-Being: Synthesis. Washington, DC: Island Press.

Morandin LA., Winston ML., Abbott VA., Franklin MT. 2007. Can pastureland increase wild bee abundance in agriculturally intense areas? Basic and Applied Ecology 8:117-124. DOI: 10.1016/j.baae.2006.06.003.

Morandin LA., Winston ML. 2005. Wild bee abundnace and seed production in conventional, 

organic, and genetically modified canola. Ecological Applications 15:871-881.

Morandin LA., Winston ML. 2006. Pollinators provide economic incentive to preserve natural land in agroecosystems. Agriculture, Ecosystems \& Environment 116:289-292. DOI: 10.1016/j.agee.2006.02.012.

Natural Resources Canada. 2006. Canada's National Forest Inventory: Area, Gross Total Volume by Forest/Non-forest, Forest Type, Age Class. Available at nfi.nfis.org/home.php?lang=en

Nelson E., Mendoza G., Regetz J., Polasky S., Tallis H., Cameron Dr., Chan KM., Daily GC., Goldstein J., Kareiva PM., Lonsdorf E., Naidoo R., Ricketts TH., Shaw Mr. 2009. Modeling multiple ecosystem services, biodiversity conservation, commodity production, and tradeoffs at landscape scales. Frontiers in Ecology and the Environment 7:4-11. DOI: $10.1890 / 080023$.

Nielsen SE., Bayne EM., Schieck J., Herbers J., Boutin S. 2007. A new method to estimate species and biodiversity intactness using empirically derived reference conditions. Biological Conservation 137:403-414. DOI: 10.1016/j.biocon.2007.02.024.

North Saskatchewan Watershed Alliance. 2012.North Saskatchewan Watershed Overview. Available at www.nswa.ab.ca/content/overview

Parisien MA., Kafka VG., Hirsch KG., Todd JB., Lavoie SG., Maczek PD. 2005.Mapping wildfire susceptibility with the BURN-P3 simulation model. Available at www.firegrowthmodel.ca (accessed April 13, 2016).

Parker DC., Manson SM., Janssen MA., Hoffmann MJ., Deadman P. 2003. Multi-agent systems 
798

799

800

801

802

803

804

805

806

807

808

809

810

811

812

813

814

815

816

817

818

Parker DC., Hessl A., Davis SC. 2008. Complexity, land-use modeling, and the human dimension: Fundamental challenges for mapping unknown outcome spaces. Geoforum 39:789-804. DOI: 10.1016/j.geoforum.2007.05.005.

Pick FR. 2016. Blooming algae: a Canadian perspective on the rise of toxic cyanobacteria. Canadian Journal of Fisheries and Aquatic Sciences 73:1149-1158. DOI: 10.1139/cjfas-

Renard KG., Foster GR., Weesies GA., McCool DK., Yoder DC. 1997. Predicting soil erosion 2015-0470

Ricketts TH., Regetz J., Steffan-Dewenter I., Cunningham SA., Kremen C., Bogdanski A., Gemmill-Herren B., Greenleaf SS., Klein AM., Mayfield MM., Morandin LA., Ochieng’ A., Potts SG., Viana BF. 2008. Landscape effects on crop pollination services: are there general patterns? Ecology letters 11:499-515. DOI: 10.1111/j.1461-0248.2008.01157.x.

Ruckelshaus M., McKenzie E., Tallis H., Guerry A., Daily G., Kareiva P., Polasky S., Ricketts T., Bhagabati N., Wood SA., Bernhardt J. 2013. Notes from the field: Lessons learned from using ecosystem service approaches to inform real-world decisions. Ecological Economics 115:11-21. DOI: 10.1016/j.ecolecon.2013.07.009.

Ruan, X., Qiu F., Dyck M. 2016. The effects of environmental and socioeconomic factors on land-use changes: a study of Alberta, Canada. Environmental Monitoring and Assessment 
820 Schieck J., Song SJ. 2006. Changes in bird communities throughout succession following fire 821 and harvest in boreal forests of western North America: literature review and meta-analyses. 822 Canadian Journal of Forest Research 36:1299-1318. DOI: 10.1139/x06-017.

823 Serrouya R., D’Eon R. 2004. Variable retention forest harvesting: research synthesis and 824 implementation guidelines. Edmonton, Alberta. Available at http://www.sfmnetwork.ca/docs/e/SR_200405serrouyarvari_en.pdf

826

827

828

829

830

832

833

834 835

836

837

838

839

Sheffield CS., Frier SD., Dumesh S. 2014. The bees (Hymenoptera: Apoidea, Apiformes) of the Prairies ecozone, with comparisons to other grasslands of Canada. In: Giberson DJ, Cárcamo HA eds. Arthropods of Canadian Grasslands (Volume 4): Biodiversity and Systematics Part 2. Biological Survey of Canada, 427-467.

Skog KE. 2008. Sequestration of carbon in harvested wood products for the United States. Forest Products Journal 58:56-72.

Soil Landscapes of Canada Working Group. 2010. Soil Landscapes of Canada version 3.2. Available at sis.agr.gc.ca/cansis/nsdb/slc/v3.2/index.html

Soulé M. 2013. The “new conservation.” Conservation Biology 27:895-897. DOI: 10.1111/cobi.12147.

Statistics Canada. 2015a. Farm cash receipts, annual. Table 002-0001. Available at www5.statcan.gc.ca/cansim/a34?lang $=$ eng\&mode $=$ tableSummary\&id $=0020001 \&$ stByVal $=$ $2 \& p 1=-1 \& p 2=9$

Statistics Canada. 2015b. Logging industries, principal statistics by North American Industry 
840

841

842

843

844

845

846

847

848

849

850

851

852

853

854

855

856

857

858

859

860

Classification System. Table 301-0007. Available at

http://cfs.nrcan.gc.ca/statsprofile/economicimpact/ab

Tallis H., Lubchenco J. 2014. A call for inclusive conservation. Nature 515:27-28. DOI: $10.1038 / 515027 \mathrm{a}$.

Trimbee AM., Prepas EE. 1987. Evaluation of total phosphorus as a predictor of the relative biomass of blue-green algae with emphasis on Alberta lakes. Canadian Journal of Fisheries and Aquatic Sciences 44:1337-1342. DOI: 10.1139/f87-158

Tymstra C., Bryce RW., Wotton BM., Taylor SW., Armitage OB. 2010. Development and Structure of Prometheus: the Canadian Wildland Fire Growth Simulation Model. Available at www.firegrowthmodel.ca (accessed April 13, 2016).

Villamor GB., Le QB., Djanibekov U., van Noordwijk M., Vlek PLG. 2014. Biodiversity in rubber agroforests, carbon emissions, and rural livelihoods: An agent-based model of landuse dynamics in lowland Sumatra. Environmental Modelling and Software 61:151-165. DOI: 10.1016/j.envsoft.2014.07.013.

Wall GJ., Coote DR., Pringle EA., Shelton IJ. 2002. RUSLEFAC - Revised Universal Soil Loss Equation for Application in Canada: A Handbook for Estimating Soil Loss from Water Erosion in Canada. Ottawa, Ontario.

Wang T., Hamann A., Spittlehouse DL., Murdock TQ. 2012. ClimateWNA-high-resolution spatial climate data for western North America. Journal of Applied Meteorology and Climatology 51:16-29. DOI: 10.1175/JAMC-D-11-043.1.

Wieland R., Ravensbergen S., Gregr EJ., Satterfield T., Chan KMA. 2016. Debunking trickle- 
861 down ecosystem services: The fallacy of omnipotent, homogeneous beneficiaries.

862 Ecological Economics 121:175-180. DOI: 10.1016/j.ecolecon.2015.11.007.

863 Wilensky U. 1999.NetLogo. Available at http://ccl.northwestern.edu/netlogo/ 


\section{Table 1 (on next page)}

Attributes of the ecosystem services modelling system.

Table adapted from Bagstad et al. (2013b). 


\begin{tabular}{ll}
\hline Criterion & Attributes \\
\hline Quantifiable, approach to uncertainty & $\begin{array}{l}\text { Quantitative, uncertainty though varying inputs } \\
\text { (which can be automated in NetLogo) }\end{array}$ \\
\hline Time requirements & $\begin{array}{l}\text { Moderate to high, mostly for finding data and } \\
\text { GIS pre-processing }\end{array}$ \\
\hline Capacity for independent Application & Yes \\
\hline Level of development \& & Initial models complete and documented. Further \\
documentation & model development is ongoing \\
\hline Scalability & Regional, watershed, or landscape scale \\
\hline Generalizability & High, with local data requirements \\
\hline Nonmonetary \& cultural perspectives & $\begin{array}{l}\text { Biophysical values for all ES, and monetary } \\
\text { values for some. Currently no cultural values. }\end{array}$ \\
\hline Software and model code are free downloads. \\
Most appropriate as a regional tool; relative \\
with existing environmental \\
assessment
\end{tabular}


Figure 1

Study area in Alberta, Canada.

Region includes the North Saskatchewan River and Battle River watersheds in central Alberta. Inset map depicts the region's location within Alberta (grey area) and Canada.

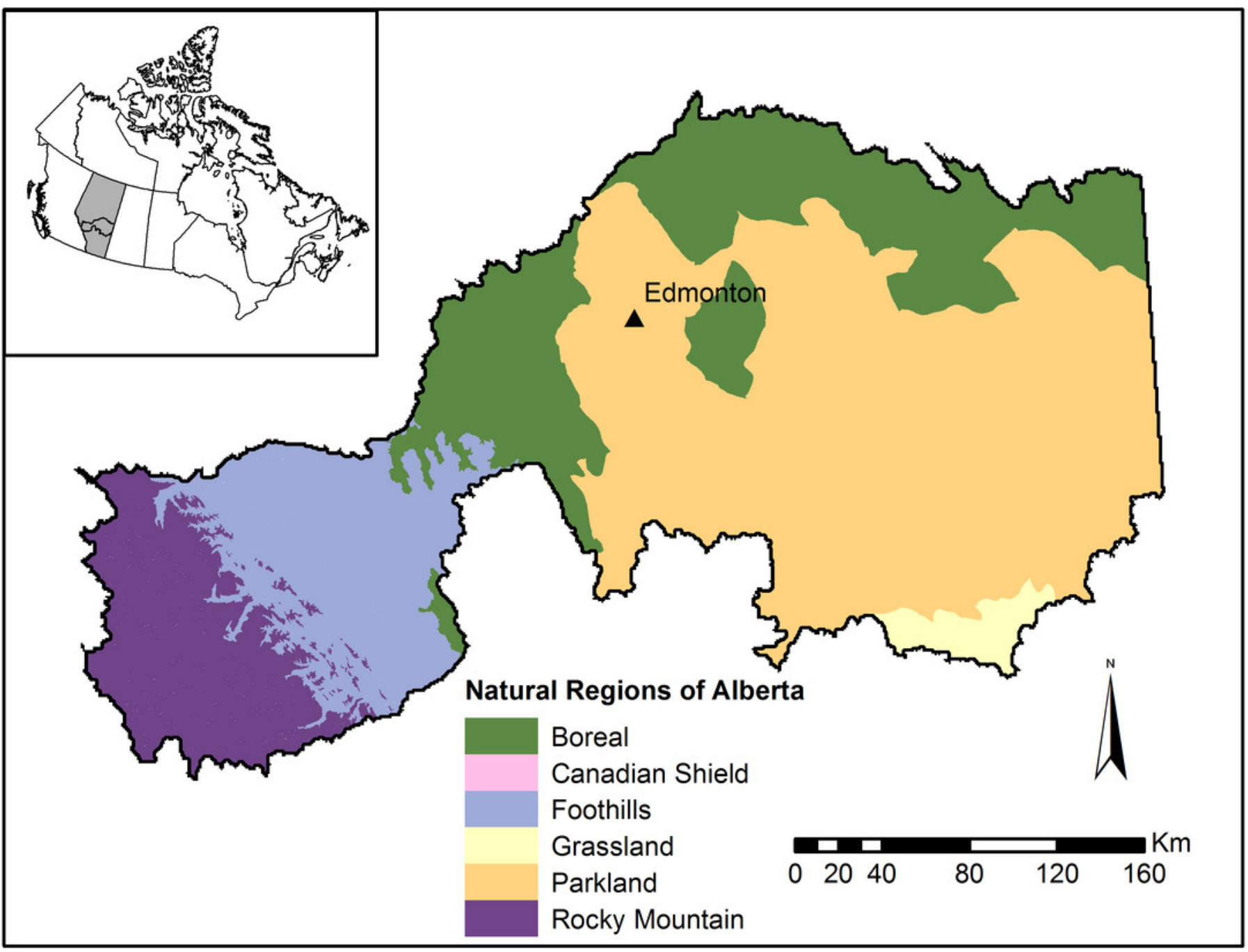


Figure 2

Major landcover types in the North Saskatchewan watershed region of Alberta, Canada.

Representative sample landscapes in unharvested forest, harvested forest, grassland, and agricultural areas are outlined in black.

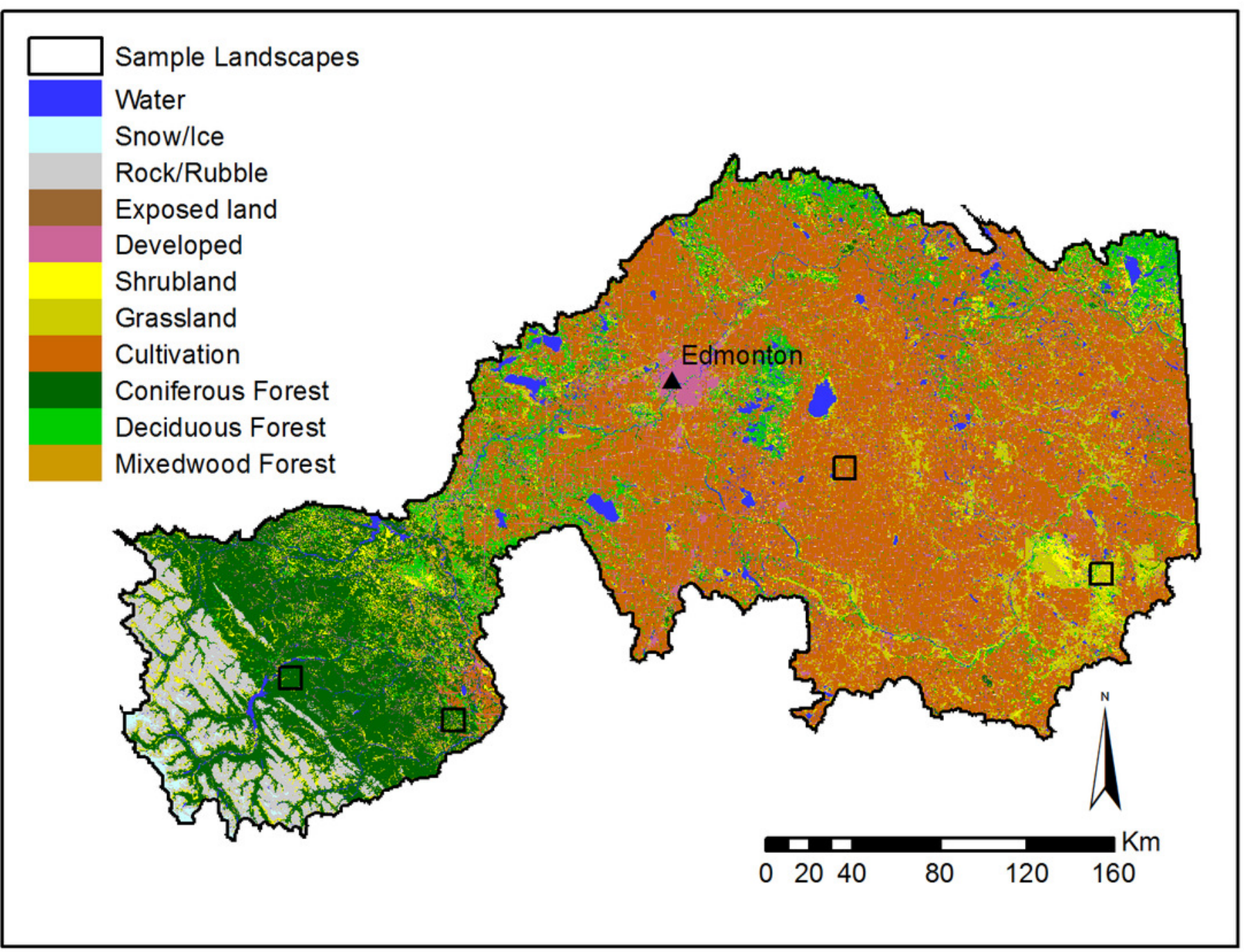




\section{Figure 3}

Modelled net present value of 20-year simulated timber harvest.

Modelled timber net present value in the active forestry area of the North Saskatchewan watershed region of Alberta, Canada, based on a 20-year forest harvest simulation under (A) standard clearcutting practices, and (B) variable retention timber harvest. Map is restricted to the active forestry area of the North Saskatchewan watershed. 

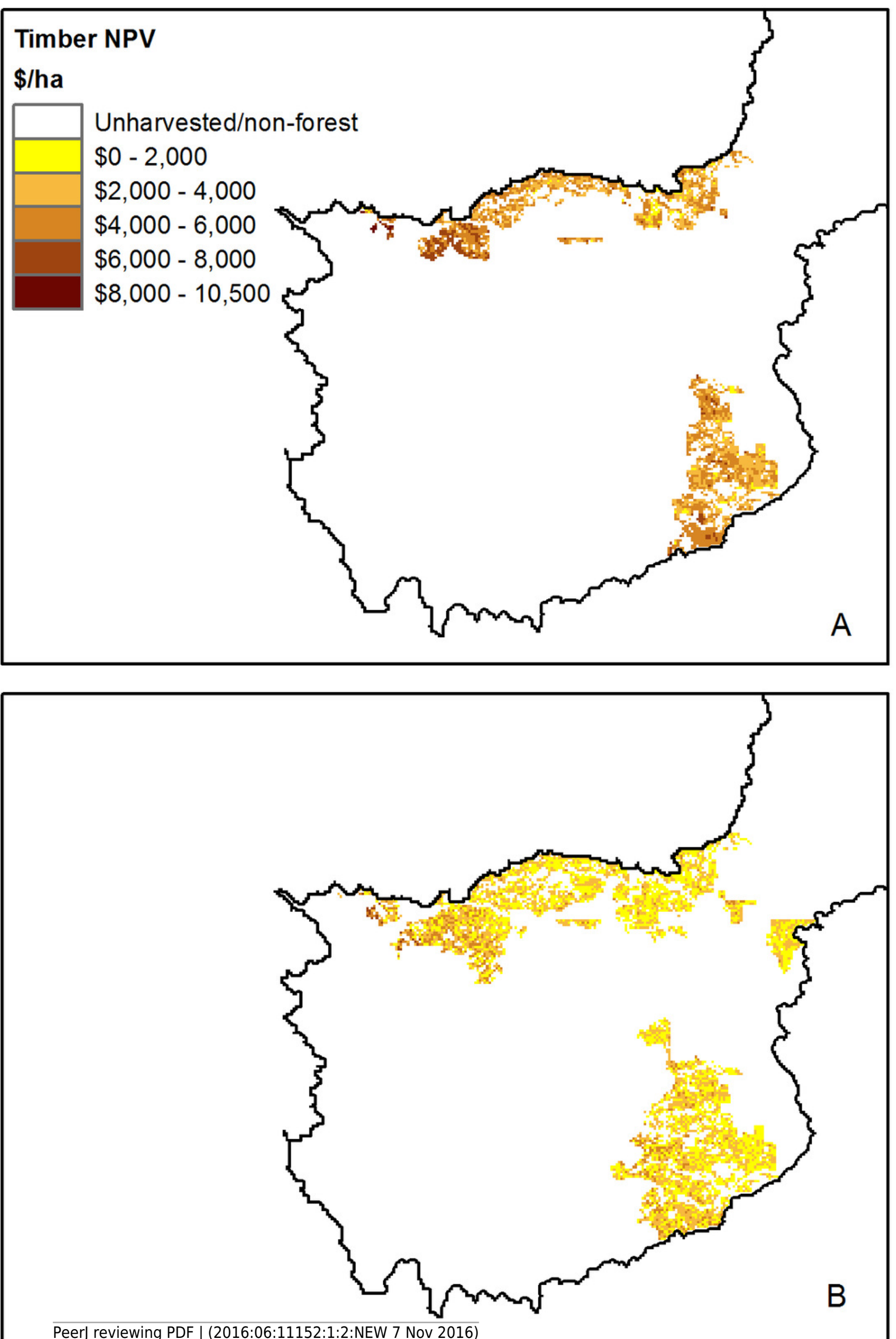
Figure 4

Modelled forest carbon storage under current (2010) landscape conditions.

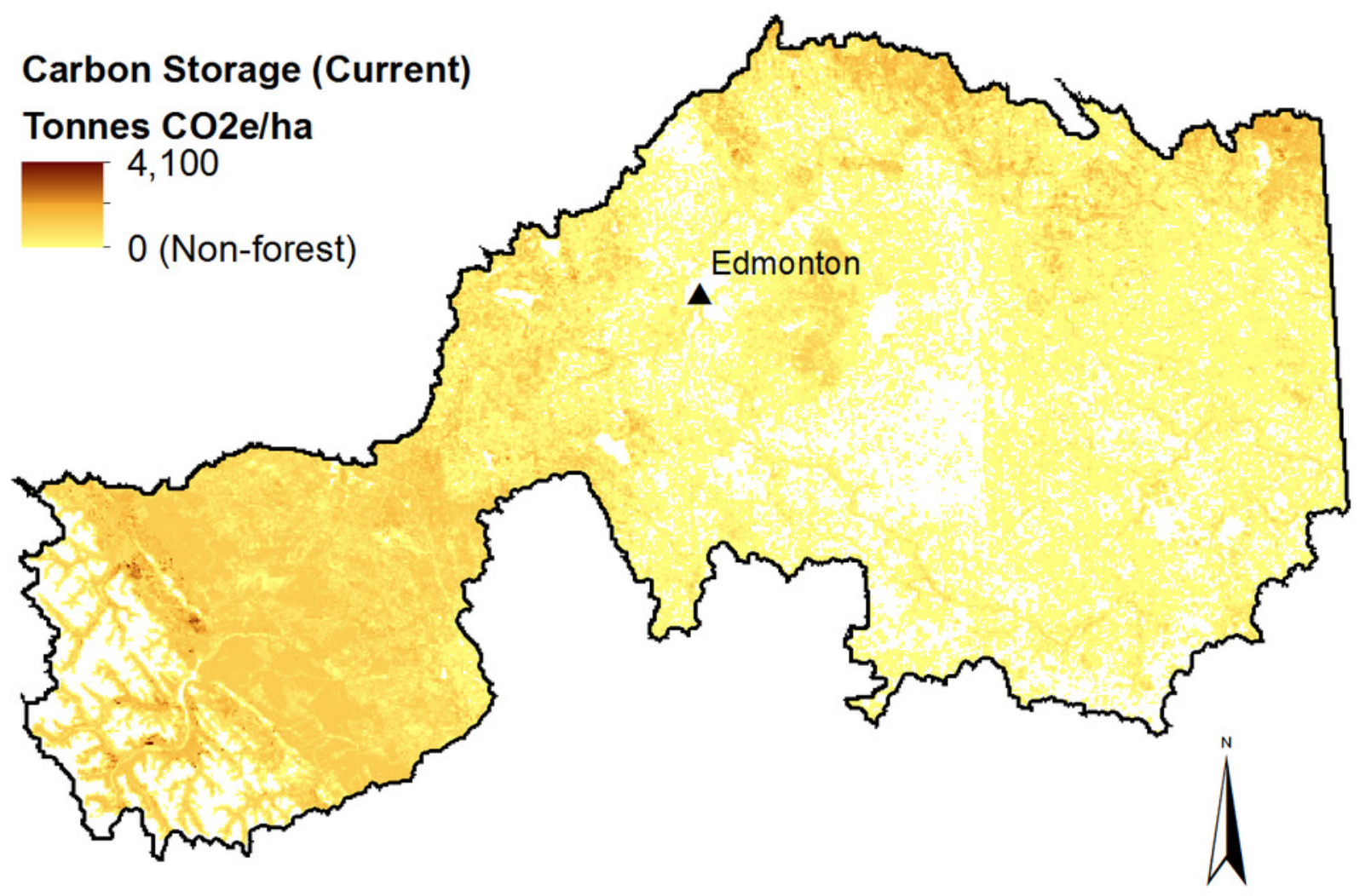

\begin{tabular}{lllll}
\hline & 20 & & & \\
0 & 20 & 80 & 120 & 160
\end{tabular} 
Figure 5

Modelled change in forest carbon storage following timber harvest.

We simulated 20 years of timber harvest under standard clearcutting practices, and recorded the change in carbon storage from a baseline of 2010. Map is restricted to the active forestry area of the North Saskatchewan watershed.

\section{Change in Carbon Storage}

Tonnes CO2e/ha

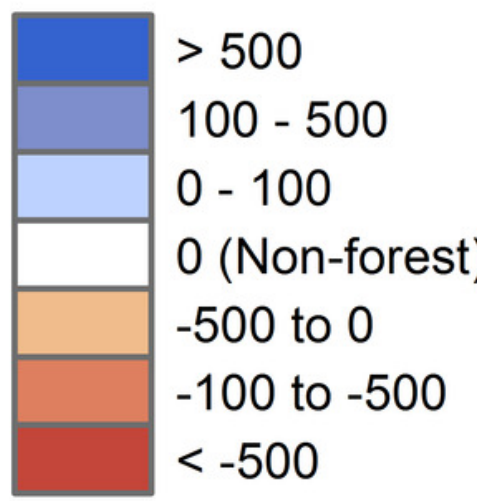

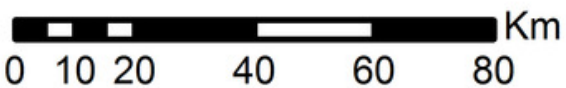

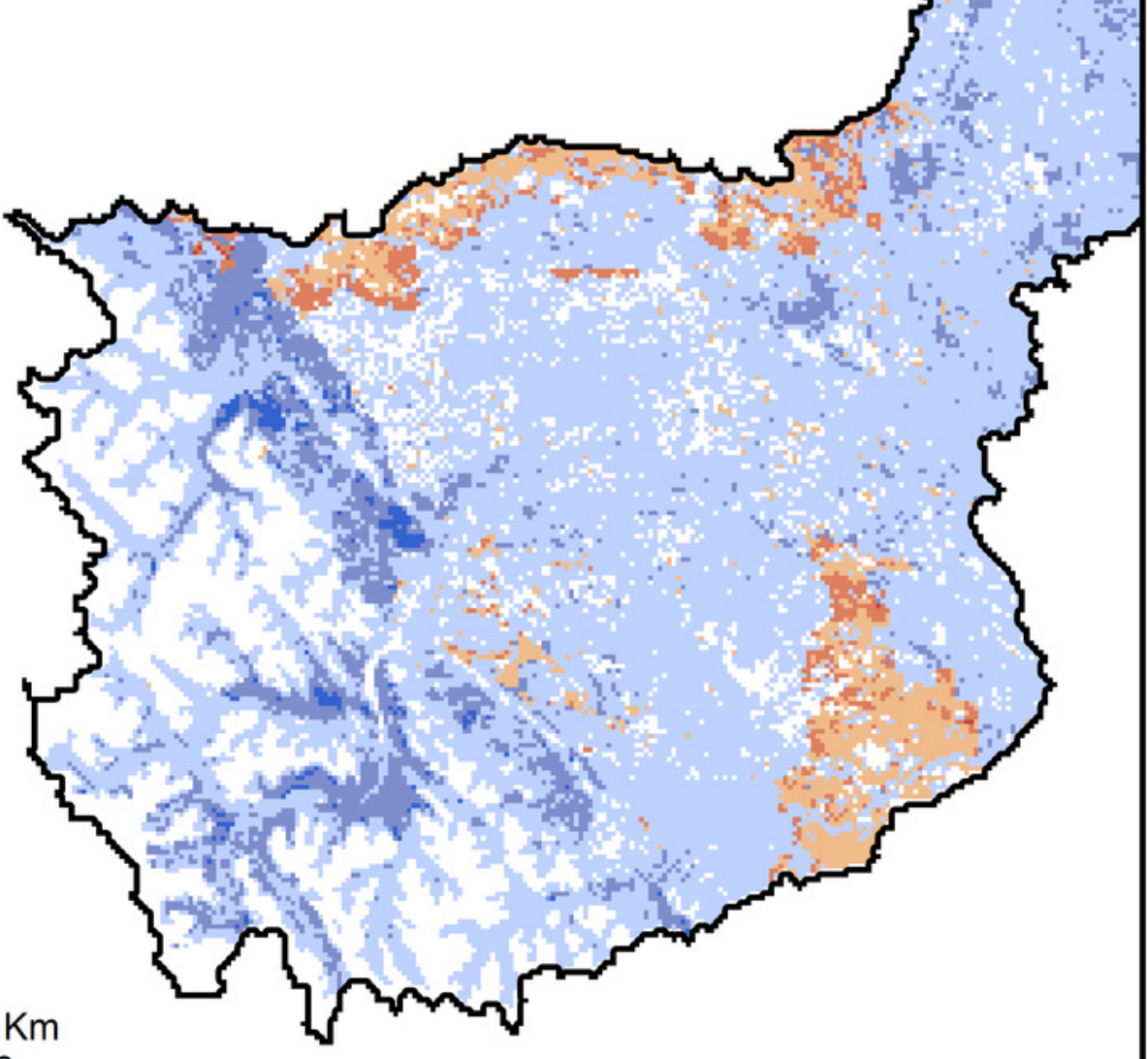


Figure 6

Modelled phosphorus loading into surface runoff.

Phosphorus supply represents all phosphorus released by the landscape. Loading is based on average precipitation from the 1971-2001 climate normals. Major lakes (> 300ha) and rivers are also depicted.

\section{Phosphorus Loading}

$\mathrm{kg} / \mathrm{ha} / \mathrm{yr}$
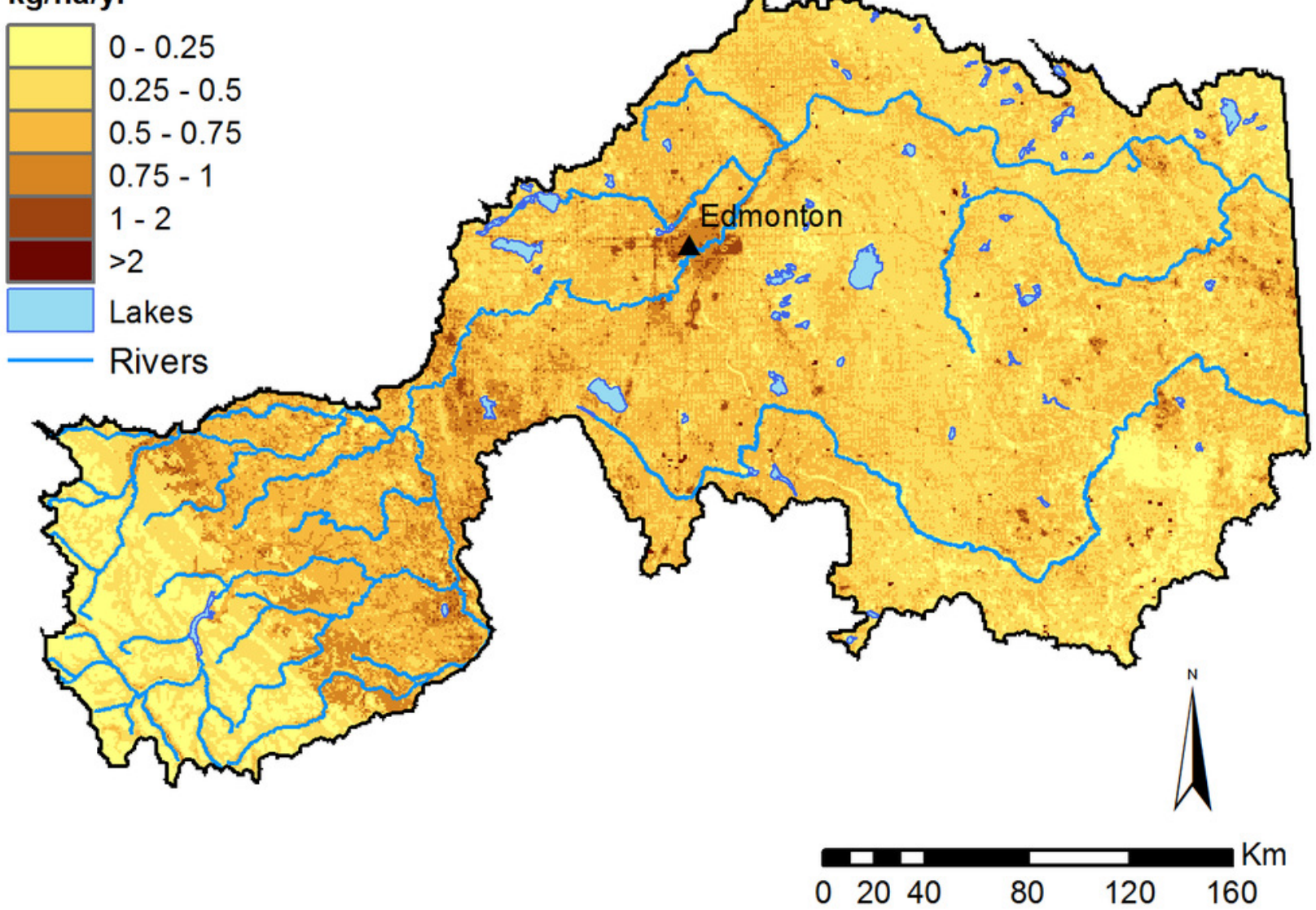


\section{Figure 7}

Modelled phosphorus supplied by sub-basins to the river network.

Phosphorus supply represents all phosphorus released by the landscape that is not subsequently retained by the landscape during overland flow. Phosphorus supply is based on average precipitation from the 1971-2001 climate normals. Sub-basins upstream of the City of Edmonton are outlined in grey.

\section{Phosphorus Supplied to River}

$\mathrm{kg} / \mathrm{year}$ (thousands)

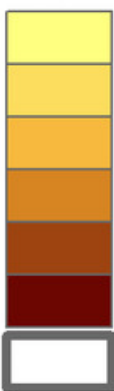

$<50$

$50-100$

$100-150$

$150-200$

$200-250$

250 - 300

Upstream Sub-basins

Rivers
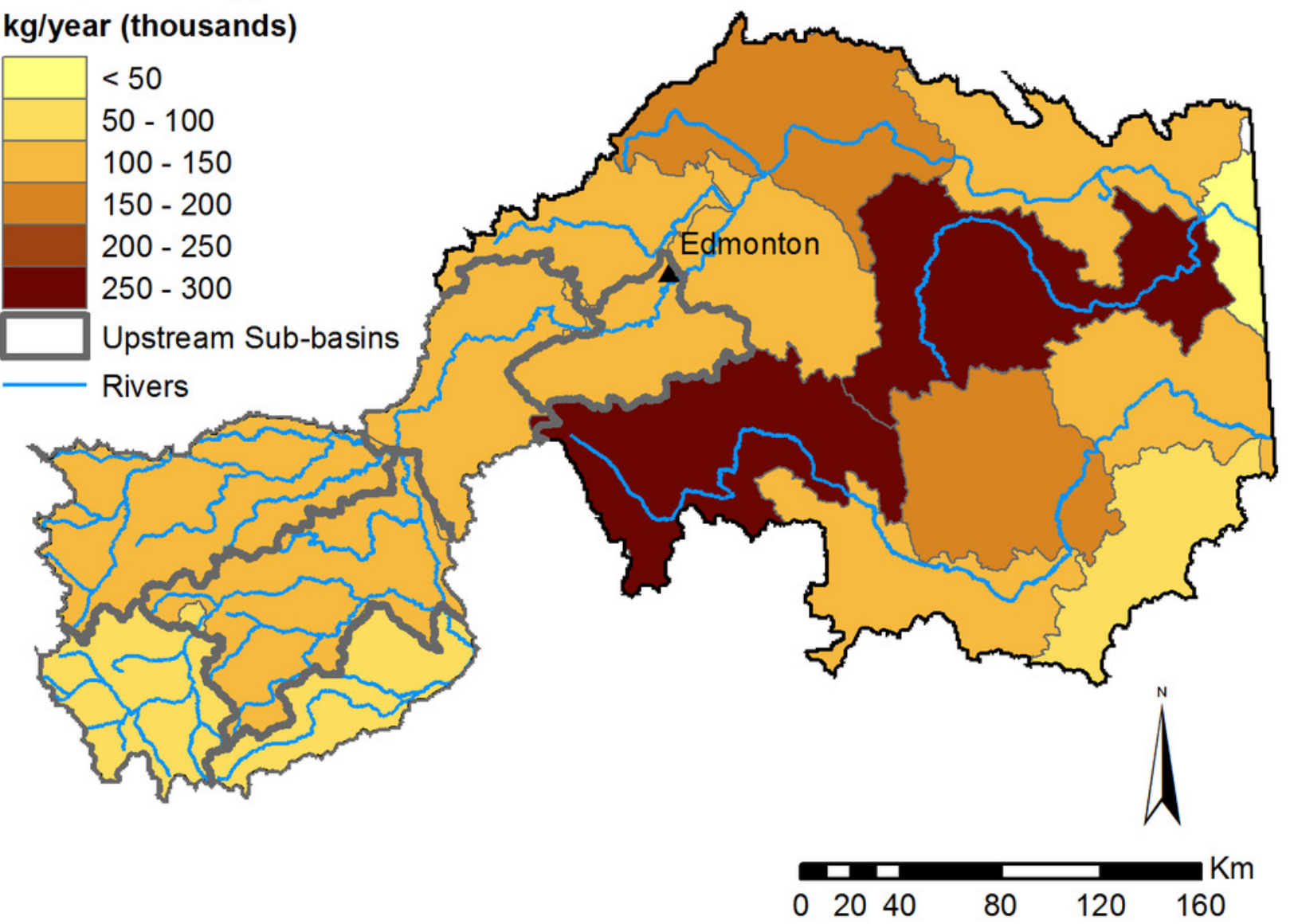
Figure 8

Modelled net present value of pollination for canola production.

Modelled pollination value is based on a 4-year crop rotation using crop type maps from 2009-2012.

Pollination NPV

(\$/ha - 4-year Rotation)

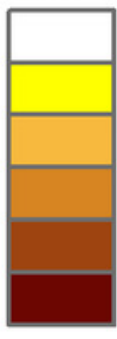

0

$<\$ 100$

$\$ 100-200$

$\$ 200-300$

$\$ 300-500$

$>\$ 500$
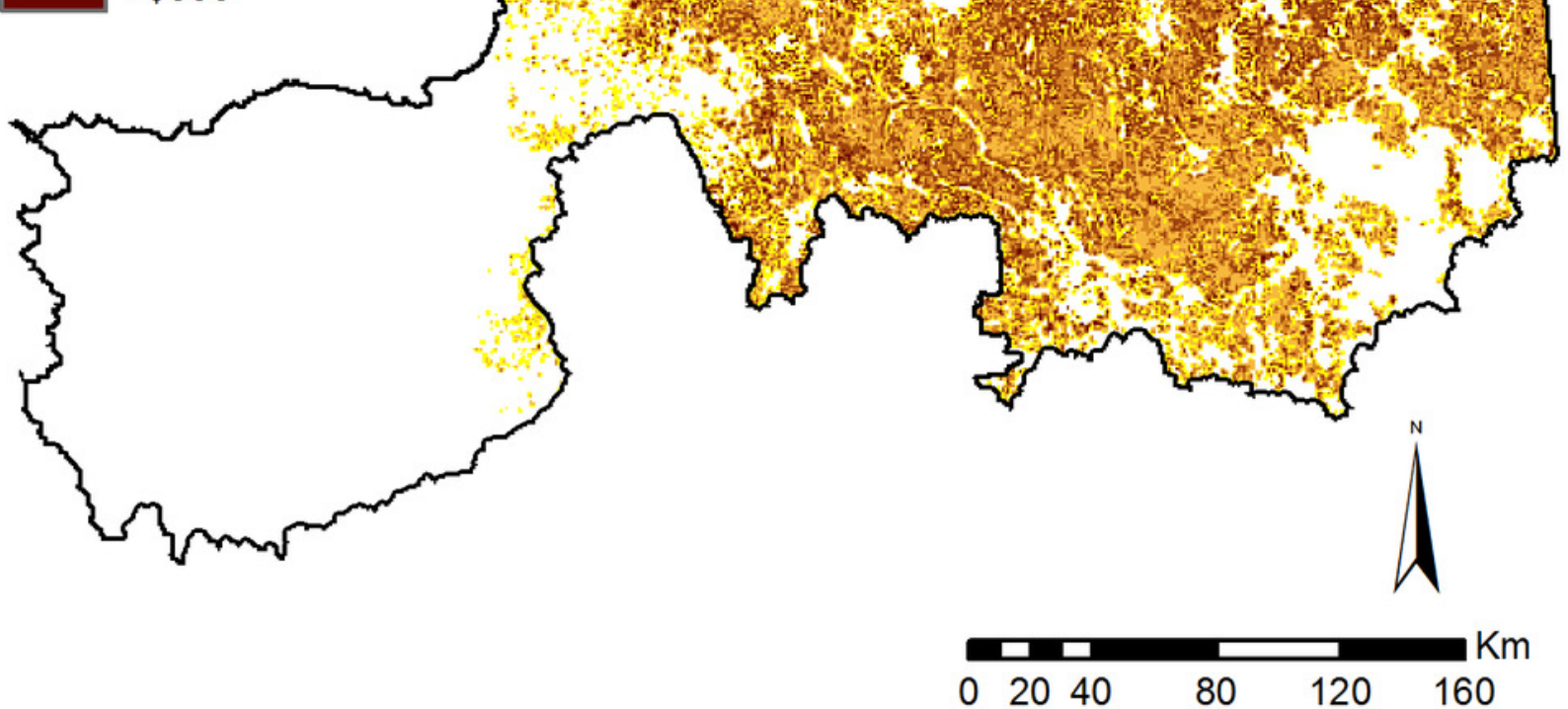
Figure 9

Modelled biodiversity index under current (2010) landcover conditions.

\section{Biodiversity Index}

\section{Value}

\begin{tabular}{|l|l|}
\hline $90-100 \%$ \\
$80-90 \%$ \\
$70-80 \%$ \\
$60-70 \%$ \\
\hline $50-60 \%$ \\
\hline $40-50 \%$ \\
$30-40 \%$ \\
$20-30 \%$ \\
$10-20 \%$ \\
\hline $0-10 \%$ \\
\hline
\end{tabular}
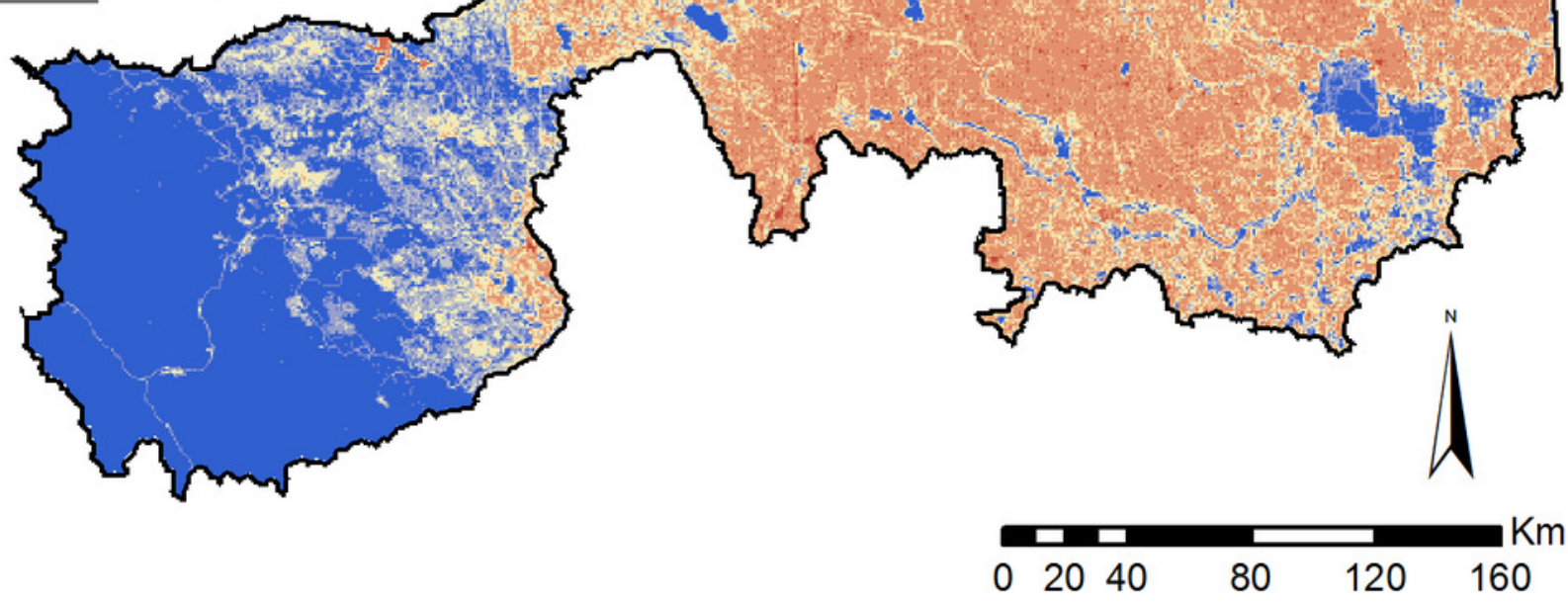


\section{Figure 10}

Comparison of clearcutting versus variable retention timber harvest.

Modelled impacts of two timber harvest strategies on a suite of ecosystem services compared to current landscape conditions. Both timber simulations were run for a 20-year period, and results are standardized to the current landscape. Because there is no timber value prior to the timber harvest simulations, the clearcut simulation was assigned a value of $100 \%$ for timber value. 


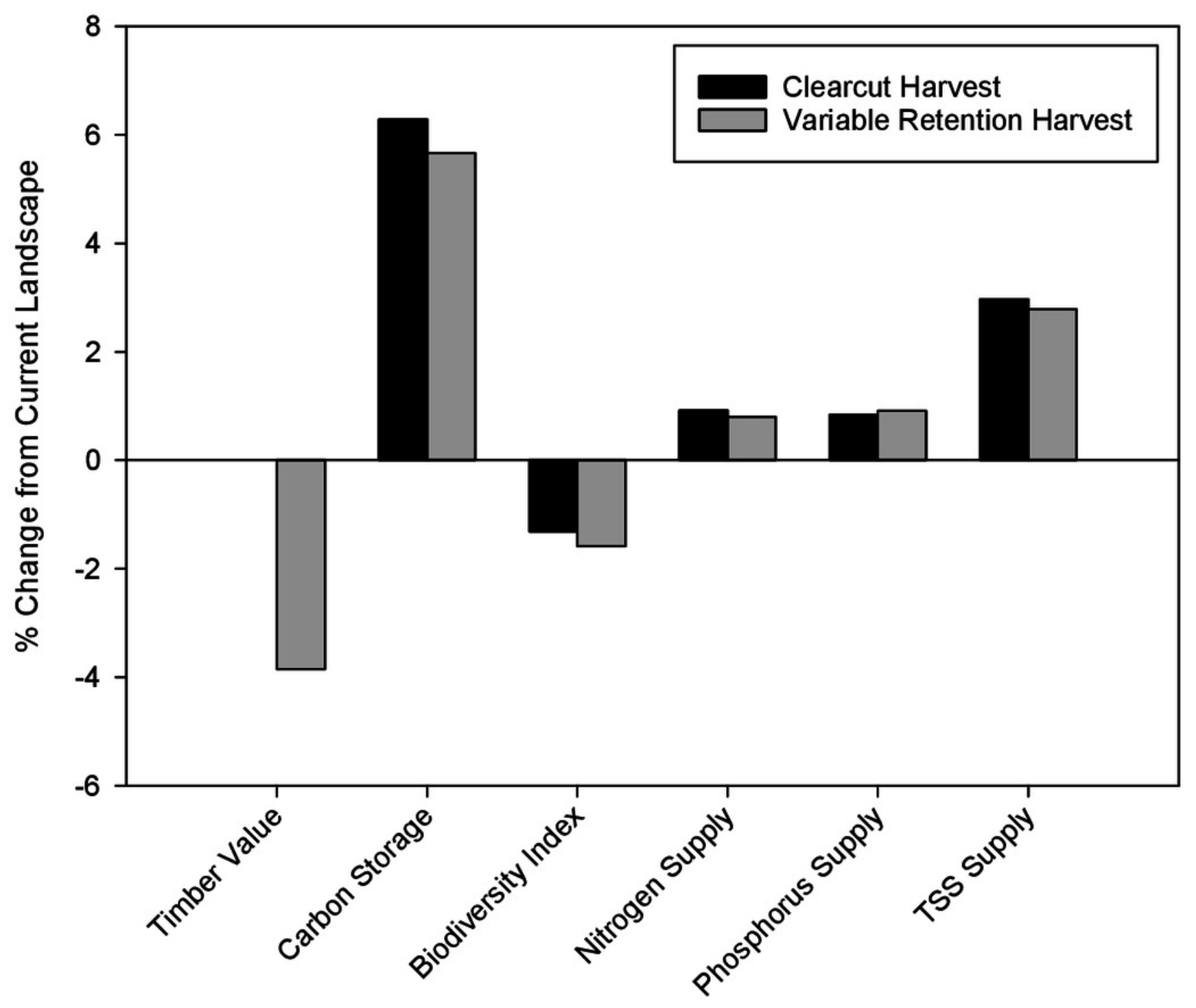




\section{Figure 11}

Modelled biodiversity index following 20-years of simulated timber harvest.

Map represents the predicted biodiversity responses to (A) standard clearcutting practices, and (B) variable retention timber harvest. Map is restricted to the active forestry area of the North Saskatchewan watershed. 


\section{Biodiversity Index}

\begin{tabular}{|l|l}
\hline $90-100 \%$ \\
$80-90 \%$ \\
$70-80 \%$ \\
$60-70 \%$ \\
\hline $50-60 \%$ \\
$40-50 \%$ \\
$30-40 \%$ \\
$20-30 \%$ \\
$10-20 \%$ \\
$0-10 \%$ \\
\hline
\end{tabular}
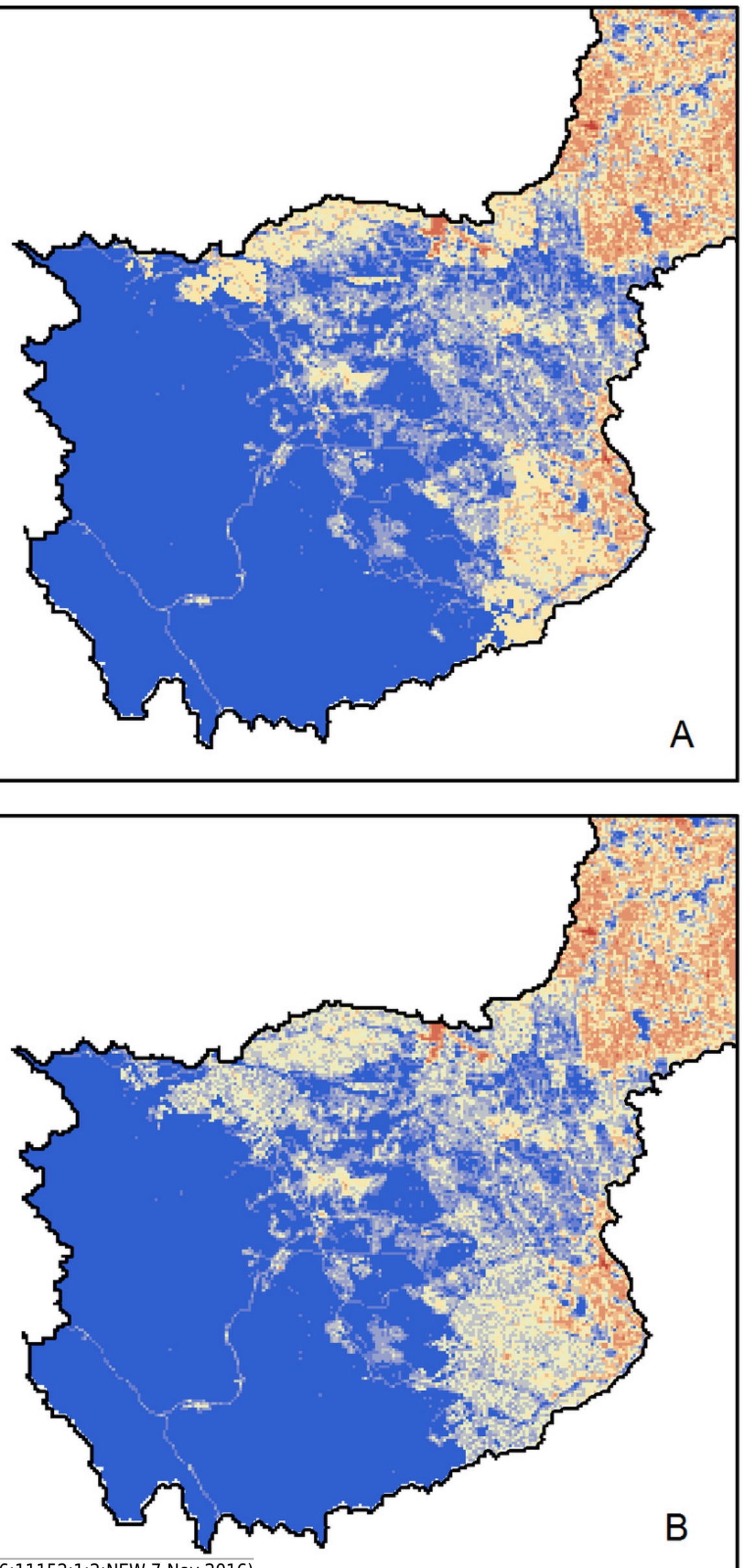


\section{Figure 12}

Suite of ecosystem services provided by four representative $100 \mathrm{~km}^{2}$ landscapes.

All axes represent scores standardized from $0-100 \%$. For pollination, timber, carbon, and phosphorus runoff, the highest value obtained from the four sample landscapes was artificially set as $100 \%$. The biodiversity index was obtained directly from the model.

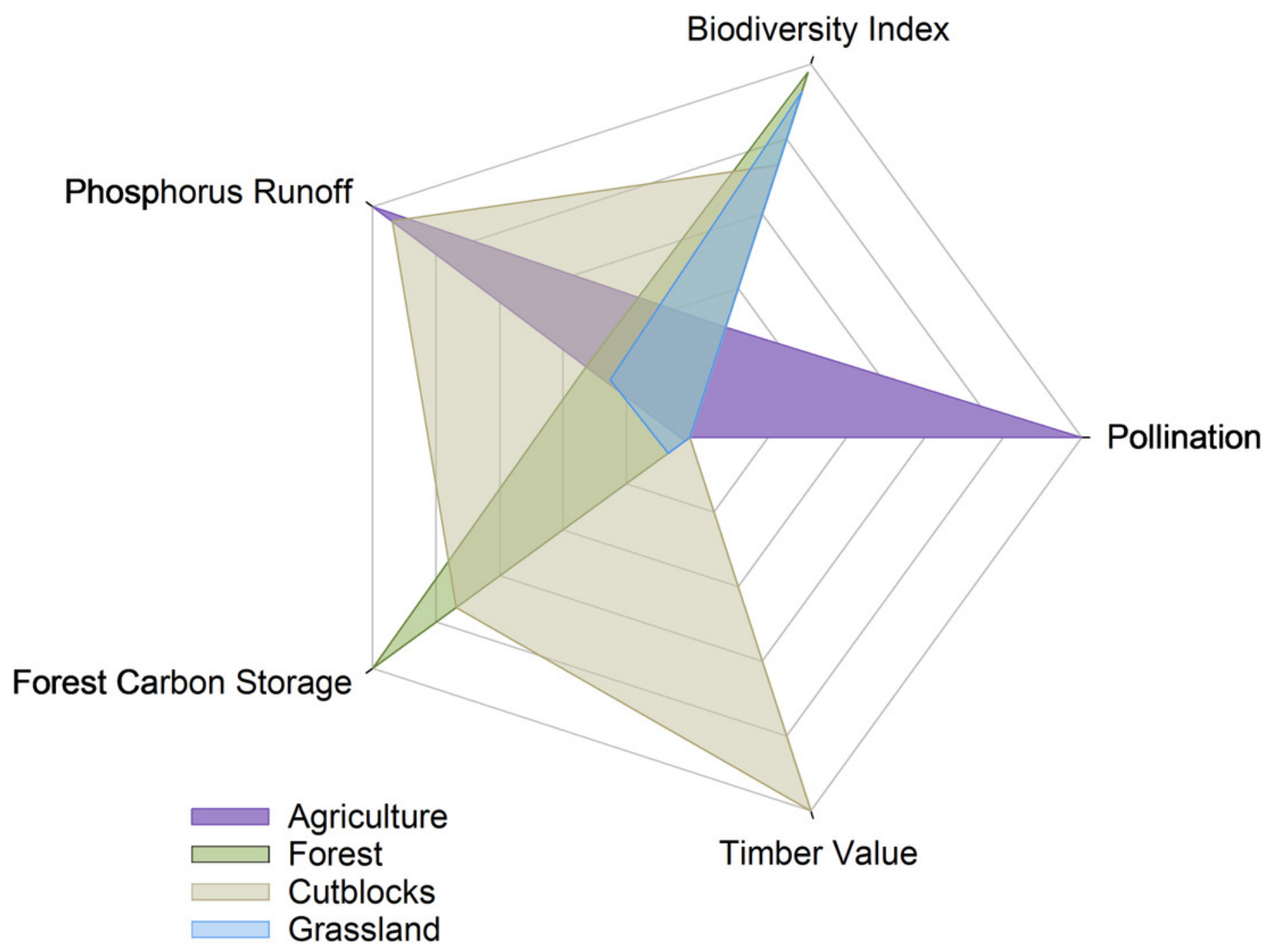




\section{Figure 13}

Effect of simulated agricultural expansion on pollinator value and total crop revenue.

Modelled response of canola revenue (A), total pollination value (B), and per-field pollination value $(C)$ to increasing amounts of agricultural conversion in the North Saskatchewan watershed region of Alberta, Canada. 

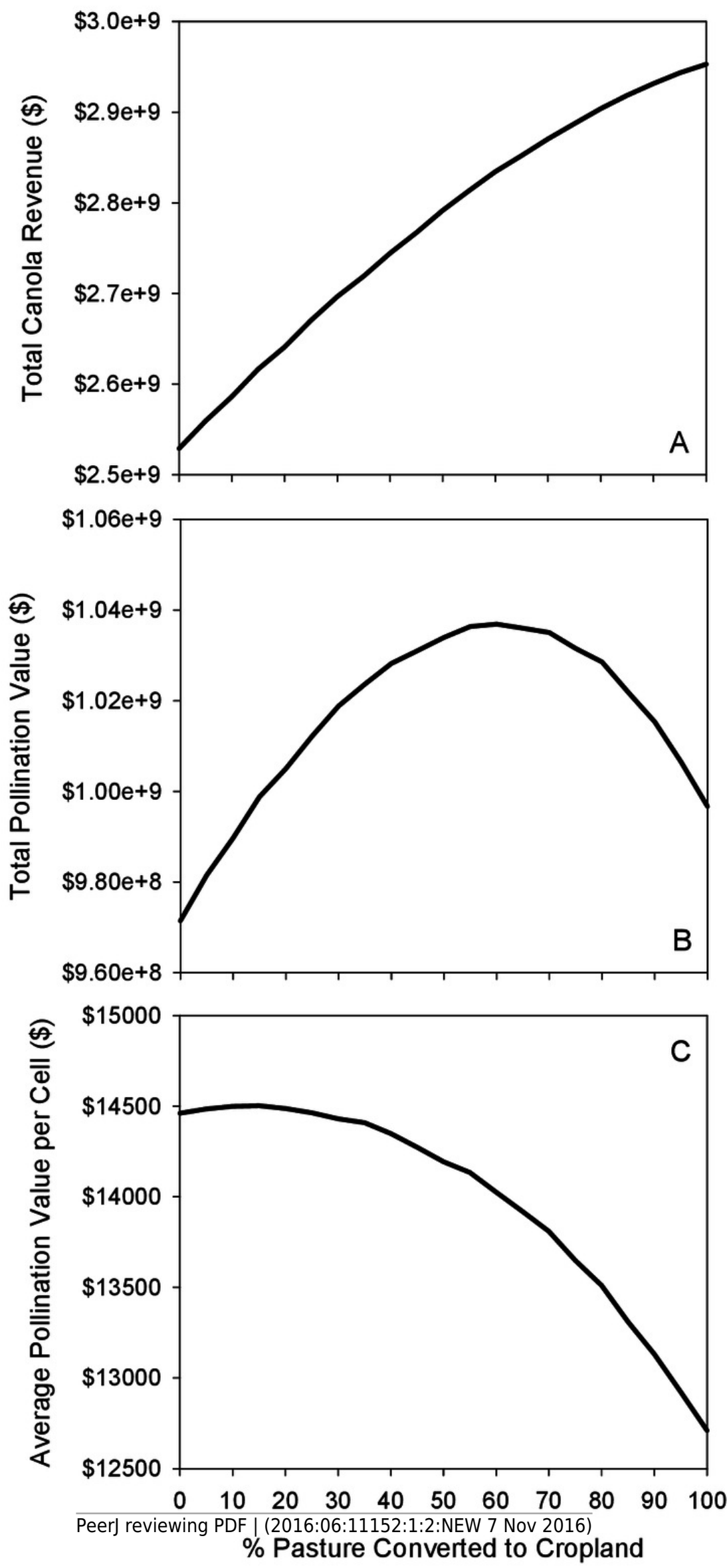


\section{Figure 14}

Effect of simulated agricultural expansion on biodiversity and water quality.

Modelled response of biodiversity index (A) and phosphorus supply (B) to increasing amounts of agricultural conversion in the agriculture-dominated portion of the North Saskatchewan watershed region of Alberta, Canada. 

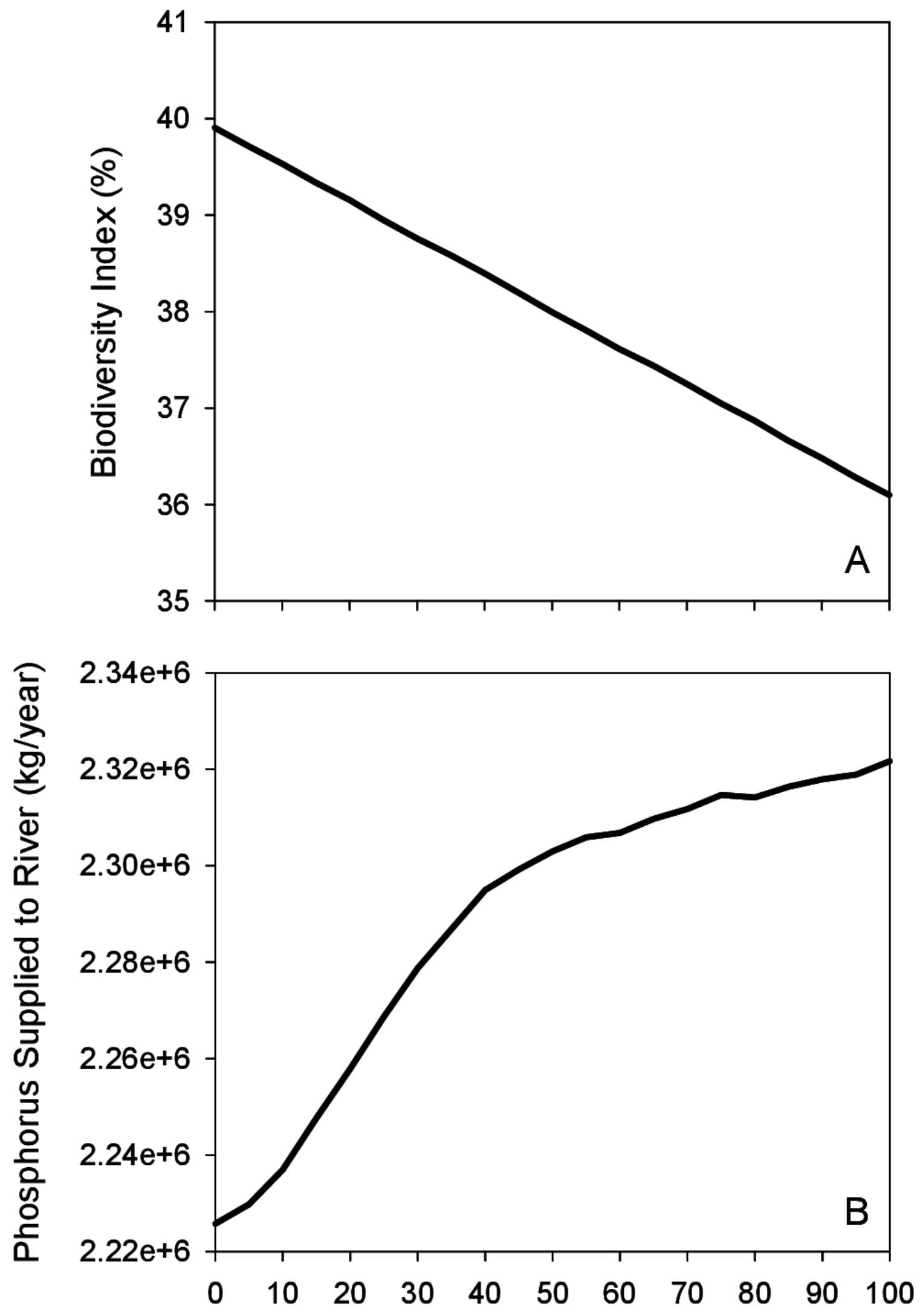